\title{
The Twenty-First Amendment and State Control Over Intoxicating Liquor: Accommodating the Federal Interest
}

\author{
Sidney J. Spaeth†
}

In recent years, the Supreme Court has begun diluting the twenty-first amendment. The twenty-first amendment implemented the hard-fought lesson of liquor's tumultuous past in this country: liquor control has to be local to be effective. Although the Court has been abandoning its earlier deference to state liquor statutes, it has continued to speak deferentially of legislation passed under a core purpose of the twenty-first amendment. This Comment derives a three-step accommodation analysis to review state liquor statutes that conflict with federal laws. The dispositive initial inquiry asks whether an actual conflict exists. If there is a conflict, the Court must conduct a purpose-based analysis to determine if the state passed the statute under a core power. A statute passed under the core power must bear a rational relationship to its intended purpose. The analysis concludes by arguing that if the statute is found to lie outside the core purpose of the amendment, the Court should balance the competing state and federal interests under a traditional preemption analysis.

\section{INTRODUCTION}

Henry Wirkkula, a confectioner from Big Falls, Minnesota, was driving home with his wife and two daughters at about 11:30 p.m. on June 8, 1929. As Wirkkula drove through a border patrol hquor checkpoint fifteen miles south of the Canadian border, rookie U.S. Customs Agent Emil Servine ordered him to halt. After proceeding about ten more feet in the process of stopping his car, Wirkkula was dropped by a fusillade of five rounds fired from a sawed-off shotgun by a second rookie custoins agent, Emmit White. Wirkkula died instantly. No hquor was found. ${ }^{1}$

$\dagger$ A.B. 1983, Stanford University; J.D. candidate 1991, University of California, Berkeley. The author wishes to thank Barbara and Molly Spaeth, Professor Michael Smith, Kim Smith, Sakthi Murthy, Jessica Vapnek, Carolyn McNiven, and the staff of the California Law Review.

1. 71 CoNG. REC. 2625 (1929) (statement of Rep. Schafer) (citing a June 9, 1929, Associated Press report from The Washington Post). Wirkkula's name was corrected from the initial report, and some facts were added. See id. at 2671 (statement of Rep. Pittenger); Koochiching County 
The enforcement of Prohibition represented the nadir of government regulation of hquor. Wirkkula's was ouly one of many shooting deaths which the government justified by its goal of banning liquor. ${ }^{2}$ But his death best exemplified the nation's outrage at often violent Prohibition enforcement. $^{3}$

The United States learned a hard lesson from Prohibition. The drunken revelry of the nineteenth-century saloon, and its often exaggerated image, sent Ameriea careening toward national prohibition. This great national experiment failed utterly. Commumities that opposed liquor enibraced the dry years, but the federal government was unable to enforce Prohibition im communities that had accepted-and even expected-hard drink.

The hard lesson learned fron nationwide prohibition was formalized into the twenty-first amendment, which gives states vast power to regulate the importation, distribution, and transportation of alcoholic beverages within their borders. The twenty-first amendment places control of hquor regulation where it belongs-in the communities that feel the impact of these laws. ${ }^{4}$ This authority extends to all laws enacted under the amendnient's core power-activities related to the regulation of consumption, importation, and distribution of liquor. In effecting this core power, states are enipowered to establish a regulatory scheme to monitor the flow and production of liquor, and to prevent the diversion of hiquor into commerce without its first being channeled through regulatory safeguards.

These regulations, of course, often conflict with federal laws or interstate commerce. The positive grant of power to Congress to regulate interstate commerce has long been considered to carry its negative: that is, Congress nray restrict state action that hinders interstate commerce. ${ }^{5}$ State regulations that contravene federal law are also invalid under the

Coroner's Inquest at International Falls, Minn. (June 10, 1929), reprinted in 71 CoNG. REc. 3130 (1929).

2. E.g., 71 Cong. Rec. 2671 (1929) (statement of Rep. Pittenger); L. SchMeckebier, The Bureau of Prohibition: Its History, ACtivities aNd ORganization 53 (1929) ("A too free use of firearms has been one of the criticisms directed against prohibition agents, and alleged cases of unjustifiable use of weapons have been reported.").

3. See 71 CoNG. REc. 2671 (1929) (statement of Rep. Pittenger):

If prohibition can only be enforced by the use of sawed-off shotguns in the hands of irresponsible Government agents, then indeed, have we reached the high tide of fanaticism and bigotry in this matter. We have reached a point where responsible citizens have not only the right but the duty to replace prohibition with some method of Government control under which law and order will prevail.

4. "The transportation or importation into any State, Territory, or possession of the United States for delivery or use therein of intoxicating hquors, in violation of the laws thereof, is hereby prohibited." U.S. CoNST. amend. XXI, § 2.

5. See, e.g., L. TRIBE, AMERICAN CONSTITUTIONAL LAw 403-13 (2d ed. 1988) (discussion of judicial interpretation of this negative inplieation). 
supremacy clause. ${ }^{6}$ These preemptive and dormant powers of Congress clash with the twenty-first amendment's instruction that states should regulate hiquor.

The Supreine Court analyzes state liquor regulations that collide with federal law within a framework of an accommodation principle. Under this analysis, the Court has held that state liquor regulations must be given deference. The Court's apphication of this deferential standard, however, has been inconsistent and misleading. Recent Court decisions have used deferential language, yet have apphed a scrutiny seemingly indistmguishable from the scrutiny apphed to laws regulatimg other matters of commerce.

These decisions have strangled inuch of the vitality from the twentyfirst amendment. By treating hiquor as just another article of commerce, the Court's decisions ignore lessons learned over a century of internal discord in this country. History has proven that hiquor is different, and the Constitution recognizes that difference. ${ }^{7}$ By refusing to affirm consistently the states' powers to regulate liquor, the Supreme Court has taken a step toward nullifying the twenty-first amendment. This moveinent culminated in a 1990 decision $^{8}$ that replaces the deference toward state liquor regulations coinpelled by the twenty-first amendinent with a sclieme authorizing congressional preemption of liquor control.

This Cominent seeks to mold tlie congressional intent behind the twenty-first amendment and the Supreme Court's treatinent of liquor regulation laws into a framework that will protect the states' regulatory power, while providimg a vigilant guard agamst state overreaching under the guise of hquor control. It argues that the twenty-first amendment trumps the dormant commerce clause and the supremacy clause whenever a state undertakes to protect a core power secured by the amendment. The Court should adhere to a deferential view of state hquor regulations passed for a proper purpose under the twenty-first amendment's core power. To effectuate that proper purpose, a state inay regulate the consuinption, distribution, inanufacture, or transportation of intoxicating drink.

This Comment suggests a three-part accommodation test that first asks the dispositive question of whether an actual conflict between state and federal law has arisen. ${ }^{9}$ If no conflict surfaces, the state statute does

6. Id. at 479.

7. See, e.g., Hostetter v. Idlewild Bon Voyage Liquor Corp., 377 U.S. 324, 329 (Framing the question of whether the state could bar the transportation of liquor through its boundaries, the Court wrote: "[I]t is not disputed that, if the commodity mvolved here were not liquor, but grain or lumber, the commerce clause would clearly deprive New York of any such power.").

8. North Dakota v. United States, 110 S. Ct. 1986 (1990).

9. Throughout this Comment, the term federal law should be read to mclude Congress' negative powers under the dormant commerce clause. 
not run afoul of the supremacy clause and stands as a valid exercise of the state's twenty-first amendment authority. If, however, the state statute conflicts with federal law, the accommodation test must analyze the state's purpose behind the regulation. If the regulation was enacted under a state's core twenty-first amendment power to regulate consumption, importation, or transportation of hquor, or to otherwise prevent the unlawful diversion of hquor imto state commerce, the state statute is vahid so long as it is rationally related to its proper purpose. Finally, if the statute is found to have been enacted for a purpose outside the amendment's core power, a reviewing court must weigh the competing state and federal imterests imphicated by the regulation, as part of a traditional preemption analysis.

Part I of this Comment reviews the history of state and federal liquor regulation. The Comment will explore three different eras: (1) pre-eighteenth amendment regulation; (2) the period comprising World War I, Prohibition, and the moveinent toward state control; and (3) posttwenty-first amendment regulation. This Part addresses the historical development of hquor regulation and explains the basis for the umque constitutional treatment of commerce in hiquor.

Part II discusses the accommodation test established by the Court in Hostetter v. Idlewild Bon Voyage Liquor Corp. ${ }^{10}$ This Coinment proposes a three-part analysis to articulate this accommodation principle and examines how this test operates to protect both state and federal interests in hiquor regulation. Part III reviews recent Supreme Court decisions in light of this accommodation principle and argues that the Court's statement of deferential review contradicts the inore searching scrutiny actually apphied. Finally, this Part will apply the accommodation test to North Dakota v. United States ${ }^{11}$ - the Supreme Court's latest decision on this issue-and will argue that the Court based its decision on an erroneously narrow reading of states' rights under the twenty-first amendment.

I

The Ebb and Flow of State Control Over ALCOHOLIC BEVERAGES

Despite this country's Puritan beginnings, Americans have always consumed hquor. The Puritan spirit, however, contributed to transfornmg this country in the 1800 s from a society of intemperance to a society of sobriety. ${ }^{12}$ America's disturbing experience with liquor im the $1800 \mathrm{~s}$

10. 377 U.S. 324 (1964).

11. 110 S. Ct. 1986 (1990).

12. See generally J. SAMUelson, The H1story of DR1NK 201-28 (1878) (tracing the Puritan spirit of America and how law and public opinion had an effect on the manufacture and sale of alcoholic beverages in nineteenth-century America). 
also ignited that century's relentless and consuming political war over temperance. This war was one of ideology, fueled by a puritanical distrust of alcohol. The passion inspired by the American Teinperance Society and Carry Nation's "hatchetations" led the country mexorably toward national prohibition.

Initially, the battle for temperance was local, and it was largely successful. ${ }^{13}$ If any lesson can be learned from Prohibition, it is that liquor-unlike any other article of cominerce, hicit or ilicit-cannot be subject to central planning. ${ }^{14}$ No system of hquor control has succeeded without the approval of the community. ${ }^{15}$

The failure of the eighteenth amendment largely was due to the mistaken belief that the United States was "a single cominunity in which a uniform policy of liquor control could be enforced." 16 When federal laws were passed to stop the liquor traffic, opponents eitlier went underground or ignored the laws coinpletely. Even in the nost fervent prohibitionist states, enforcement depended entirely on local opinion. As one cominentator remarked at the time:

Maine has never been and never will be a Prohibition state until public opinion precedes legal enactment. Maine is a temperance state. In the smaller county towns where there is a reasonable degree of enforceinent, it is always because behind the enforcement there is a good healthy public sentiment; and such a degree of enforcement would prevail in such communities under any law and without law ....17

\section{A. Cup of Woe}

During the 1800 s, hquor was regnlated at the local and state level. ${ }^{18}$ The federal government was passive, and when it did stir, it acted priniarily through a Congress eager to appease the states and to provide niore statutory authority for state control.

State enforcement, however, varied in vigor. The Northeastern States passed strict laws, but enforcenent was largely ineffective. ${ }^{19}$

13. See infra notes $20-23$ and accompanying text.

14. See id.

15. See id.

16. R. FosDicK \& A. SCOTT, TOWARd LIQUOR CONTROL 10 (1933).

17. Davis, Prohibition at Its Best in Maine, in The Two Banner Prohibition States 5 (1914).

18. J. SAMUELSON, supra note 12, at 216-18. Nevada reportedly had no law regulating liquor, prompting Artenus Ward to announce on his departure from Virginia City: "I never, gentlennen, was in a city where I was treated so well, nor, I will add, so often." Id. at 218 (enphasis in original) (quoting Artemus Ward). Sir C. Dilke added that in many of the state's 500 whiskey shops, "diggers might be seen tossing the whisky down their throats with a scowl of resolve as though they were coinmitting suicide, which indeed, except in poiut of speed, is probably the case." Id. (quoting C. DilKe, I Greater BRITAIN 202 (1869)).

19. See id. at 218-21 (explaining the failure of the prohibitory laws and the "ease with which liquor could be procured"). 
Legislation was most effective where it enabled localities to determine the extent of liquor sales in their midst. ${ }^{20}$ That is, where public opinion supported hquor control or prohibition, legislation was effective in raising the moral tone and general welfare of the community. But where prohibition was forced upon an unwilling community, it failed. ${ }^{21}$

This principle of "local option" was perhaps the most lasting and valuable heritage of the early temperance movement. ${ }^{22}$ Legislating drink out of many rural areas was a rather simple task and did not require a federal constitutional amendment. But in the cities, where alcohol was nost prevalent, the problems precipitated by alcohol would not disappear merely because rural majorities so wished. As one coninientator stated: "Fron the very nature of its object, prohibition is inherently difficult to enforce and when it is foisted upon a community from without its ill fate is foreordaimed."23

But this lesson of local control did not come easily to Americans, whose violent reaction to drinking was based on a repulsive inıge of the saloon that exceeded even the tawdry truth. The accounts of drinking habits im America in the early 1800 s describe practices "repulsive beyond description" and "worse than anything to be found in nodern European records." 24 According to sone accounts, drunkenness was widespread, particularly among immigrants and Native Americans, ${ }^{25}$ and the impact on society was enormous. ${ }^{26}$ One contemporary historian even attributed the destruction and demoralization of the Native Americans to the "curse" of rum and whiskey imtroduced to them by whites. ${ }^{27}$ In Kansas-where the prohibition movement was eventually anchored-some towns were said to be "ablaze with drunkenness."28 Observers in LeRoy, Kansas, $\dot{m}$ the 1850 s reported (apparently with sone degree of exaggeration) that "the whole town was drunk." 29

20. Id. at $226-27$.

21. Id.

22. J. KOREN, AlCOHOL AND SOCIETY 73 (1916).

23. Id. at 95 .

24. J. SAMUELSON, supra note 12, at 204.

25. Id. at 205.

26. One state passed a law in 1821 handing over to the court the property of habitual drunkards - putting them on the same plane as "lunatics." Id. at 205. In the popular mind, alcohol was also linked to poverty, crime, and disease. For example, the trustees of an almshouse in Baltimore, Maryland, reported in 1827 that 554 of 623 adults admitted to the house had fallen into poverty by excessive drunkenness. Id. at 206. The chaplain of the New York state prison at SingSing reported that 75 percent of prisoners acknowledged being habitual drunkards, while 44 percent confessed that they had committed crimes under the influence of alcohol. Id. During a cholera epidemic in Albany, New York in 1832, one author reported that out of 336 deaths, 140 victims were "hard drinkers" and 55 "drank freely." Id.

27. Id. at 206-07 (citing 2 J. BuckinghaM, AMERICA, Historical, Statistical and DESCRIPTIVE 304 (1841)).

28. R. BADER, Prohibition in KANSAS: A History 22 (1986).

29. Id. 
It was image, though, more than substance, that fanned the prairie fire toward temperance. The "aura of debauchery and degradation which for a century Americans associated with the old-time saloon"30 created and fueled the temperance movement. One commentator recreated the exaggerated eighteenth-century view of saloons:

What is difficult for the unburned to remember is that the saloon was more than an altar of fellowship. It was also a place where dirty old men spat on the floor and conspired toward the subversion of public and private moralities, where the fathers of young children floated away a week's wages that could have gone to food, clothing, and education. It was a place where addiction enslaved many a man, imsulating him from the lifestyle of decency and responsibility by sinking him into a blurred phantasmagoria of whores, drug fiends, pimps, thieves, and gamblers. Such phrases are in part an exercise in literary license, but they evoke images essential to understanding a reality as it was understood by Prohibitionsts. To approach that reality is to fix the mind's eye ... upon a sort of metaplorical slave ship in middle passage, upon the images of sodden drunks, of hideously fat men sucking stale cigars, of toilets fouled with vomit and urine in the haze of alcololic narcosis, of the blind idiocy of drunken violence. But the license is not mere local color. To dismiss these images as high camp would be to dismiss the absolute seriousness of millions of men ... and it would be to ignore a crucial issue in two hundred years of American life. ${ }^{31}$

Moreover, unlike im modern society where many view alcoholism as a disease that can afflict perfectly respectable people, the nineteentl1century image of the drunkard was riddled with terror. It evoked images of men, "[i]mprovident to the brink of madness," who threw their wages to booze and gamblers, debauched girls and women, befouled respectable citizens, and then targeted the dregs of their lechery and violence upon their families. "This image ... was seared across the American conscience." 32

Whatever the reality of the country's drinking problem, the ubiquitous image of the debauched saloon turned public opimion against liquor. While temperance societies date back to the Middle Ages, ${ }^{33}$ the

30. N. Clark, Deliver Us From Evil: AN INTERPRetation of American Prohibition 1 (1976).

31. Id. at 2.

32. Id. at 2-3. Charles Jewett menorialized this image in 1840, in a verse written for Sunday school:

Shoeless, over frozen ground

His wretched children go

And away he staggers to where the sound

of drunken revel is ringing round

To taste his cup of woe.

Id. at 3.

33. In Germany, emperors, princes, counts, ecclesiastics, and burghers organized temperance 
American temperance movement started slowly in the early $1800 \mathrm{~s}^{34}$ The cornerstone for the movement was laid by Lyman Beecher, a preacher whose passionate attacks on modern morality, particularly its weakness for hquor consumption, in the early 1800 s were emulated by ministers in every state. ${ }^{35}$ The first successful political inoveinent against drink began in 1826 with the founding of the American Society for the Proinotion of Teinperance, better known as the American Temperance Society (ATS). ${ }^{36}$ The ATS swelled to one thousand affiliated societies by 1829. These societies succeeded remarkably ${ }^{37}$ and soon garnered support froin inainstreain society. ${ }^{38}$ By 1835 , eight thousand temperance societies claimed 1.5 million ineinbers, which represented about twelve percent of the free population of the United States, and possibly as many as one in five adults. ${ }^{39}$

In its early stages, teinperance reform rehed exclusively on moral persuasion directed toward the consumer. Eventually, however, reformers sought to coinpel temperance by focusing on the supplier, rather than the drinker. Old-style temperance revivals continued, but suppressing the saloon became the top priority. ${ }^{40}$

The first major breakthrough for this new temperance strategy occurred in Maine. Neal Dow, an advocate of moderation who turned into a teetotaler, became the driving force behind the nation's first real prohibition law, passed in Maine in $1851 .^{41}$ Dow's triumph in Maine motivated teinperance workers nationwide and within four years, thirteen states had "Mame laws."42

societies (Orden der Mässigkeit) to combat liquor as well as swearing. J. SAMUELSON, supra note 12 , at 106, 239.

34. The first such group may have been the Massachusetts Society for the Suppression of Intemperance, founded in 1813. J. BLOCKER, AMERICAN TEMPERANCE MOVEMENTS: CYCLES of REFORM 11-12 (1989).

35. See N. Clark, supra note 30 , at 31.

36. J. BLOCKER, supra note 34 , at 12.

37. Within three years of the formation of the ATS, 50 distilleries had closed, 400 merchants had stopped selling liquor, and 1,200 drunkards had been reformed. The tally of imported spirits fell from 5,285,000 gallons in 1824 to 1,195,000 gallons in 1830. J. SAMUELSON, supra note 12, at 240.

38. Shipowners paid higher wages to temperance captains, a Boston insurance company paid a five percent rebate for every vessel that did not carry liquors, and the military not only prohibited the distribution of hiquor to soldiers, but also replaced spirit rations with extra rations of sugar and coffee. Id.

39. J. BLOCKER, supra note 34, at 14.

40. See id. at 25-27; J. KoREN, supra note 22, at 69. When the battle over Prohibition reached its climax in the years before the ratification of the eighteenth amendment, some were already pointing to the shift away from moral suasion as the great failure of the temperance movement. Cyrus W. Davis, secretary of state of Maine from 1911 to 1912, wrote, "In the old days real temperance effort bore real fruit, for it was directed against the drinker .... It recognized the trite truism that the average man can no more be made an abstainer by law than he can be made religious by law." Davis, supra note 17, at 5-6.

41. N. Clark, supra note 30 , at 36.

42. Id. at 45 . 
These laws, however, prohibited only the manufacture and sale of "spirituous or intoxicating liquors." They did not prohibit personal consumption - the goal was merely to abolisl public drunkenness. ${ }^{43}$ There is little evidence that Maine laws affected most of the residents of these states. ${ }^{44}$ Moreover, eight of the thirteen "Maine law" states saw their laws struck down entirely or in part by state courts prior to the Civil War. ${ }^{45}$ As these laws fell one by one, the temperance moveinent made no concerted effort to prop them up again. For a brief period, the temperance movement waned. As pohtical einergencies-most notably the slavery question-arose in the states, major political parties clung to any friend they could find, wet or dry. ${ }^{46}$

While hittle was done to interfere with the manufacture and sale of liquor during the Civil War, the issue of prohibition was not forgotten. Abraham Lincohi reportedly said on the day of his death that, after Reconstruction, the conntry's next question would be the suppression of legalized liquor. ${ }^{47}$ As soon as the war ended, the temperance moveinent started up again, and the National Prohibition Party was organized in 1869. The "woinen's war" emerged soon thereafter. In 1874, the Women's Christian Teinperance Umon met for the first time. ${ }^{48}$

The history of tension over the liquor issue in Kansas illustrates, in an extreine fashion, the events transpiring across the country in the 1800 s. Isolated outbreaks of violence against saloons had begun in Kansas by 1855 . These attacks often involved women, whose weapon of choice was the liatchet. ${ }^{49}$ But it was not until Carry Nation's celebrated "liatchetations" on Kansas saloons beginning in 1900, that contmuity caine to this tactic. ${ }^{50}$ In the Spring of 1900, Carry Amelia Nation made her first out-of-town foray, traveling twenty miles by buggy from lier home in Medicine Lodge to Kiowa, where slie attacked three saloons with rocks and brickbats. Three months later, she attacked the finest hotel in Wichita: the Hotel Carey. ${ }^{51}$ Nation's acts not only prompted

43. Id. at $45-46$.

44. Id. at 47. State legislatures and local governments did little to enforce the laws. In Portland, Maine, wliere Neal Dow was mayor and was determined to prove the laws could work, opponents flouted Prolibition. Some storekeepers stopped selling grog, but cliarged a nickel for a soda cracker, whiclı was served with a free drink. Others cliarged admission to see a "blind pig," the viewing of whicl entitled the buyer to a free tumbler of rum. Id. at $47-48$.

45. Id. at 48.

46. Id.

47. Id. at 50 .

48. Id.

49. See id. at 16-18. Twice in the summer of 1856 , a dozen of the most prominent women in Lawrence armed themselves witl "axes, liatcliets, and liammers, or whatever they could best use for the purpose," and attacked a log cabin saloon. Id. at 17.

50. See id. at 133-34.

51. Id. at 135. While history has often viewed Carry Nation's activities somewhat comically, they were no joke. In 1901 in Winfield, Kansas, 2,000 men responded to Nation's call to rally 
many to beheve her insane, ${ }^{52}$ but also threatened to divide the prohibition movement. Her acts demonstrated that hiqor opponents could no longer merely pontificate, but had to act. ${ }^{53}$

The sheer fervor and self-righteousness of the temperance inovement galvanized its support. While some believed the temperance movement reeked of fanaticism, conventional wisdom held that temperance was probably a good thing, promoting domestic tranquility through sobriety. ${ }^{54}$ Moreover, across the country, the temperance banner was carried by the formidable Anti-Saloon League (ASL), a federation of churches and temperance societies that evolved into one of the most powerful pohitical organizations in United States history. ${ }^{55}$

After making the shift in strategy from proselytizing of drinkers to widespread reform, the first step in the ASL's evolutionary process was to sponsor local and state legislation regulating saloons. ${ }^{56}$ The ASL then moved for "local option" laws. ${ }^{57}$ The ASL eventually infiltrated the entire pohtical process, using voter initiatives and developing a system to review, monitor, and endorse candidates for pohitical office. ${ }^{58}$ Despite

against illegal saloons. They were armed with 500 rifles and 2 cannons to protect their churches, which had become fortifications for the anti-saloon fanilies. Churches were stoned, homes burned, and wells poisoned, but no one was killed. The anti-saloon mob threatened to hang the flrst man who harmed one of their members; the saloons closed. Id.

52. Carry Nation has been described as "a crank, a freak, a lunatic, a bizarre clown, a sinister bigot, a demented creature, a Hitler of morals, and the Joe McCarthy of personal conduct." $R$. BADER, supra note 28 , at 140 . Nonetheless, she commanded respect from her contemporaries with her warmth, joyfulness, intelligence, and concern and sensitivity toward minorities like blacks, Jews, and Catholics. Id. at 141.

53. Id. at 135 .

54. See N. ClaRK, supra note 30 , at 6.

55. The backbone of the ASL consisted of large Protestant denominations, namely, Methodist, Baptist, Presbyterian, and Scandinavian Lutherans. These religious bodies were strongest in rural and semi-rural areas. Some argued that the ASL represented the "militant church movement." $J$. KOREN, supra note 22, at 119-20. The Roman Catholic Church, the Protestant Episcopal Church, and Jewish congregations-whose strongholds were in the cities-were identified with neither the prohibition movement nor the ASL. Id.; R. BADER, supra note 28, at 11.

The political power of the ASL is apparent in its continuing infiuence over congressional elections as late as 1926, the year most historians identify as the point it became obvious that a majority of voters had some reservations about the Volstead Act, which enforced Prohibition. N. ClARK, supra note 30, at 181; see infra notes 100-01 and accompanying text. In 1924, the Association Against the Prohibition Amendment, the ASL's political adversary, declared 262 candidates for the House of Representatives "unsatisfactory." Nonetheless, with the ASL's help, 219 of these candidates were elected to Congress. By the pivotal year of 1926, Congress-due largely to the efforts of the ASL-was drier than ever. N. CLARK, supra note 30, at 181.

56. N. ClARK, supra note 30, at 95-96.

57. Id. at 97 ("local option" laws allowed the citizens of a town, city, or county to vote on the question of licensing saloons); see supra notes 18-23 and accompanying text.

58. See generally N. CLARK, supra note 30, at 102-03 (the ASL used the Protestant pulpits to publicize its endorsements). The ASL's rapid advances did not come through moral force alone. Its fundraising was prodigious, collccting about $\$ 2.5$ million a year from 300,000 regular donors, mainly evangehical churches, during the peak of its prohibition campaigu in 1919. See id. at 112-13; J. BLOCKER, supra note 34 , at 105. 
these efforts, however, many saloons contimued to operate. ${ }^{59}$

Despite these rapid and marked advances, the temperance movement's influence remained local. The Supreme Court, however, fanned the fire toward nationwide temperance when it began asserting federal rights, substantially curtailing state authority over intoxicating hquor. ${ }^{60}$

After the Civil War, the states increased control over alcohol. This period saw the beginning of the process to annend state constitutions to make them consistent with the dry laws overruled in the $1850 \mathrm{~s}^{61}$ Kansas was the first state to go dry, with a constitutional amendment passed in $1880 .{ }^{62}$ In Mugler v. Kansas, ${ }^{63}$ the U.S. Supreme Court upheld the amendment against constitutional challenge. The Court ruled that the amendment was fairly adapted to the goal of protecting the commumity from the evils of alcohol. ${ }^{64}$

But im 1886, the Court ruled in Bowman v. Chicago Railway ${ }^{65}$ that a state could not regulate intoxicating hquor under its police power until the hquor had been physically delivered into the state, even though the state could ban the liquor entirely once it arrived. ${ }^{66}$ The Court held that states' power over liquor did not begin until transportation had terminated, because regulation of interstate commerce lay im the exclusive doinam of Congress. ${ }^{67}$

As the Supreme Court began to assert federal concerns agamst state hquor statutes, Iowa and Kansas eagerly pitched the battle to protect states' rights. Inspired by the decision im Mugler and undaunted by Bowman, the state of Iowa set out to clamp down on hiquor immediately after its arrival into the state. ${ }^{68}$ Unfortunately, Iowa encountered a clever fellow by the name of John Leisy. Leisy received a shipment of

59. The saloons in some of the cities in Prohibition Kansas were less than secret, but were politely stashed behind anterooms housing legitimate businesses, or were tucked upstairs. "[T]he saloons are banished . . . from the street floor to the second story, upon some occult theory that a nefarious transaction conducted fiftecn feet above ground ceases to be offensive to the moral sense of mankind." R. BADER, supra note 28, at 137 (quoting Kansas Sen. John J. Ingalls) (footnotes olmitted).

60. See infra notes $65-86$ and accompanying text.

61. N. ClaRK, supra note 30 , at 50 .

62. Id.; see R. BADER, supra note 28 , at 60 . Article 15 , section 10 of the Kansas Constitntion was passed by voters on November 2,1880 . The amendment provided: "The manufacture and sale of intoxicating hquors shall be forever prohibited in this State, except for medical, scientific, and mechanical purposes." KAN. CoNST, art. XV, § 10 (1880, repealed 1947).

63. 123 U.S. 623 (1887).

64. Id. at $661-62$.

65. 125 U.S. 465 (1888).

66. Id. at 499 .

67. Id.

68. Iowa statutes forbade the manufacture and sale of liquor, except for certain purposes, including those that were medicinal, cheimical, and sacramental. The statutes also forbade common carriers from bringing liquor into the state witlout receiving a certificate from the county auditor. IOWA CODE $\S \S 1523,1540-1542,1555$ (1873); 1884 Acts, cl. 143, $\S \S 10-11$. 
prohibited liquors from Illinois and put it up for sale in Iowa in unbroken kegs and cases. By becoming an agent for an out-of-state firm and selling the liquor in unbroken packages, Leisy stopped sliort of running a saloon. Nevertlieless, Iowa officials seized the liquor and Leisy sued for recovery. ${ }^{69}$ The U.S. Supreme Court ruled the seizure invalid as a restraint on interstate cominerce. The Court lield that the liquor remained an article of interstate cominerce as long as it stayed in its origmal package or container. ${ }^{70}$

While the states liad managed to get rid of the saloons, the Leisy decision opened the local agency business in liquor sales. ${ }^{71}$ The states turned to Congress and found it receptive toward lelping them regulate alcoliol. Shortly after the Leisy decision was handed down, Congress passed the Wilson Act $^{72}$ to circumvent the Leisy loophole. The Act stipulated that all liquor transported into a state would be treated the saine as liquor manufactured within the state, regardless of whether it was in its original package. ${ }^{73}$

Within two weeks of the Act's passage, Kansas officials arrested Cliarles Rahrer, wlio was conducting a package "agency" in Shawnee County for tlie local mail-order liquor liouse. Rahrer was arrested for selling one pony keg in its original package. ${ }^{74}$ The Supreme Court uplield Rahrer's arrest against a habeas corpus petition, ruling that the Wilson Act limited the cominerce clause constraints. Liquor shipped into the state could be treated by the state in the same way as liquor manufactured tliere- packaged or not. ${ }^{75}$

This victory for the prohibitionist states proved ephenreral. For while Rahrer and the Wilson Act killed the agency busniess, ingenious sellers devised a new system to skirt the laws-niail order. Upon challenge by the state of Iowa, the Supreme Court upheld the mail-order purcliase of alcoliol in Rhodes $v$. Iowa ${ }^{76}$ In Rhodes, the railroad delivered a box said to contain groceries and consigned to Williain Horu of Brigliton, Iowa. The train worker uuloaded the box onto the station platform, where it was picked up by the station agent Rhodes, who

69. Leisy v. Hardin, 135 U.S. 100, 100-02 (1889).

70. Id. at $124-25$.

71. See 21 Cong. Rec. 4954 (1890) (statement of Sen. Wilson), quoted in Dowling \& Hubbard, Divesting an Article of Its Interstate Character: An Examination of the Doctrine Underlying the Webb-Kenyon Act, 5 MiNN. L. REv. 100, 104, n.11 (1921) ("[A]gents of distilleries and breweries in other cities of the Union are already traversing Iowa and organizing the 'original package saloon' within the state, and there is no limitation as to what the original package may be.").

72. Wilson Act, ch. 728, 26 Stat. 313 (Aug. 8, 1890) (current version at 27 U.S.C. $§ 121$ (1988)).

73. Id.

74. In re Rahrer, 140 U.S. 545, 546-47 (1891).

75. Id. at 56465 .

76. 170 U.S. 412,426 (1898). 
moved the box about two yards into the freight warehouse. An hour later, police searched the crate, found intoxicating hiquor, and arrested Rhodes, charging him with unlawful transportation of intoxicating liquors. The Supreine Court, however, reversed the conviction. The Court leeld that the operation and effect of the laws of Iowa did not apply until the alcohol carried in interstate commerce was dehivered to the consignee. ${ }^{77}$ Mail-order booze, of course, flourished. ${ }^{78}$

Prohibitionist states were aghast at this new interpretation ${ }^{79}$ and sought to work around the Court's latest decision. ${ }^{80}$ Turning to Congress, the prohibitionist states once more found an agreeable partner. Senator Kenyon of Iowa lamented that the Rhodes result was "exactly what the Senate did not intend" under the Wilson Act. ${ }^{81}$

Appeals were nade to Congress to allow the states to regulate liquor as soon as it arrived in the state and prior to delivery to the consignee. Congress responded with the Webb-Kenyon Act, ${ }^{82}$ enacted in 1913. The Act used the novel approacl of stripping hquor of its interstate character, thereby renloving it froin Congress' reach under the commerce clause. The Act, constitutionally questioned fronı the start, was vetoed

77. See id. at $421-23$.

78. 49 CONG. REC. 761 (1912) (statement of Sen. Kenyon, quoting the "senior senator [Bacon] from Georgia"):

Every State in which the traffic in liquors has been prohibited by law is deluged with whisky sent in by people from other States under the shelter of the interstate-commerce law. There are daily trainloads of liquors in bottles, jugs, and other packages sent into the State consigned to persons, real and fictitious, and every railway station and every express company office in the State are converted into the most extensive and active whisky shops, from which whisky is openly distributed in great quantities. Liquor dealers in other States secure the names of all persons in a community, and through the inails flood them with advertisements of whisky, with the inost liberal and attractive propositions for the sale and shipment of the same. Freed from the expense of the iniddleman, the distiller or dealer in other States is enabled to sell to the individual in the prohibition State at a less price than the purchaser formerly paid to the domestic whisky dealer. It is evident that under such circumstances the prohibition law of a State is practically nullified, and intoxicating hquors are imposed upon its people against the will of the majority.

79. See id. Particularly galling to some was a circular distributed by an especially brash retail mail-order liquor dealer from Ogden, Utah. The circular, "illuininated with pictures of Uncle Sam, some ten in number, in various pleasing and satisfactory poses," bragged of its connection with the federal government by proclaiming, "Uncle Sam is our Partner." Id.

80. One of the more imaginative statutes passed in Mississippi. Since that state could not stop the delivery of alcohol into the state, see supra notes $76-77$ and accompanying text, the statute ordered that title to the shipment of alcohol vest immediately in the person to whom it was delivered. No one could move the booze more than 100 feet froin the delivery point. Since the recipient could not give it away, sell it, or move it outside this 100 -foot radius, she had to sit down and drink it all within this circle, or at least store it there until a later date. MISS. CODE ANN. ch. 14 (1908), cited in Dowling \& Hubbard, supra note 71, at 106 n.15.

81. 49 CONG. REC. 828 (1912) (statement of Sen. Kenyon). There can be no reasonable doubt about the intention of the Wilson Act to give a local option on liquor. "They could have prohibition, high license, local option, or free liquor, as they please. It was the intention that each State should be free to determine its own policy in regard to liquor traffic." Id.

82. Webb-Kenyon Act, ch. 90, 37 Stat. 699 (1913) (current version at 27 U.S.C. § 122 (1982)). 
by President Taft as an unconstitutional delegation by Congress to the states of the exclusive power to regulate interstate coinmerce in liquors. ${ }^{83}$ Despite this "doubtful constitutionality,"84 Congress overrode the President's veto. ${ }^{85}$ The Supreine Court subsequently upheld the constitutionality of the statute in Clark Distilling Co. v. Western Maryland Railway. ${ }^{86}$

For the time being, therefore, control of liquor was firmly in the hands of the states. ${ }^{87}$ Congress' accommodating attitude toward the states in the regulation of alcohol was so pervasive that until the outbreak of World War I, the federal governinent's interest in liquor traffic was limited to collecting excise taxes from inanufacturers and dealers. ${ }^{88}$

Ironically, lowever, it was this accommodating attitude by Congress toward state control that thrust the nation toward Prolibition. After passage of the Webb-Kenyon Act, the ASL grew more confident, setting its siglits on a constitutional amendment to circumvent the com-

83. 49 CoNG. Rec. 4291 (1913) (veto message of President Taft).

84. Id. at 4296 ("[U]nless the Supreme Court shall recede from a well-settled line of decisions extending over a long period of years it would most certainly declare this legislation to be without the constitutional powers of Congress.") (quotimg opinion letter from Attorney General Wickersham to President Taft (Feb. 28, 1913)).

85. Webb-Kenyon Act, ch. 90.

86. 242 U.S. $311,330-32$ (1917).

87. While states maintained substantial control over liquor, cases arising after Webb-Kenyon betrayed no hint of a blanket power to regulate imported liquor in the state. The cases interpreted the act as pertaining to "dry" states or states that had allowed importation only for specified restricted purposes. Comment, Retail Price Maintenance for Liquor: Does the Twenty-First Amendment Preclude a Free Trade Market, 5 HAstings CoNST. L.Q. 507, 512 n.30 (1978) (authored by Rosemary Hart). Even before the constitutionality of the Act was upheld in Clark Distilling Co., at least one court gave it this limiting construction. The Texas Court of Criminal Appeals ruled that the Webb-Kenyon Act did not authorize the states to prohibit interstate shipments of intoxicating liquor, but only authorized states to prohibit interstate shipments when the liquor was intended to be received, possessed to be sold, or used in violation of a state law. Ex parte Peede, 75 Tex. Crim. 247, 258, 170 S.W. 749, 753 (1914). This argument, according to the Texas court, found support in congressional intent:

Mr. Carlin: The purpose of this bill is not to interfere with shipments, but simply to prohibit the shipment of liquor for sale where such sale would be illegal?

Mr. Webb: Yes, sir; that is the object. The bill has been criticized by some of our temperance friends because it does not undertake to prohibit the whisky for individual use. As long as our Supreme Court holds that liquor is a legitimate subject of commerce, and as long as men have au appetite for liquor, and as long as the state does not prohibit the drinking of whisky, I do not think a law will be passed prohibiting the shipment of whisky for a man's personal use.

75 Tex. Crim. at 258, 170 S.W. at 753-54; see also Commonwealth v. One Dodge Motortruck, 123 Pa. Super. Ct. 311, 320-21, 187 A. 461, 465 (1936) (Webb-Kenyon Act ained at importation of hiquor into a state in violation of the laws of that state).

The Supreme Court wrote of the Webb-Kenyon Act:

It would be difficult to frame language more plainly indicating the purpose of Congress not to prohibit all interstate shipment or transportation of liquor into so-called dry territory and to render the prohibition of the statute operative only where the liquor is to be dealt with in violation of the local law of the State into which it is thus shipped or transported.

Adams Express Co. v. Kentucky, 238 U.S. 190, 199 (1915).

88. See L. SCHMECKEBIER, supra note 2 , at 1. 
merce clause and thus allow nationwide prohibition. ${ }^{89}$ The movement was galvanized by the fact that anti-drink sentiment was no longer a radical persuasion. ${ }^{90}$ With a victory over Taft on the Webb-Kenyon issue in 1913, the ASL focused its attention on the elections of 1914 and 1916. With inajor victories in both campaigns, dry inembers of Congress outnumbered their wet colleagues by two to one. ${ }^{91}$ At the onset of World War I, anti-drink forces had set the stage for national prohibition. ${ }^{92}$

The escalating anti-drink fervor coinbined with wartime regulation to accelerate federal control of intoxicating hiquor. In 1917, the Food and Fuel Control Act prohibited the use of foods, fruits, and other products in the production of distilled spirits. ${ }^{93}$ The first national restriction on alcohol sales was approved in 1918, after the Armistice with Germany. The War Prohibition Act forbade the sale of hquor for beverage purposes (except for export), and was to be in effect until the President decreed war deinobilization complete. ${ }^{94}$

In January of 1919, the eighteenth amendment, proposed to Congress in December of $1917,,^{95}$ was ratified. ${ }^{96}$ The amendment took effect one year later. ${ }^{97}$

As the saloon hights faded, so did state control over hiquor. ${ }^{98}$ The 1800 s had spawned such a visceral reaction to hquor that well-financed temperance inovements hurtled through the states. What had been a seemingly invincible states' rights moveinent toward local regulation of alcohol simply evaporated in the face of federal regnlation. ${ }^{99}$ Few beheved national control was appropriate, but it became law.

89. N. ClaRx, supra note 30 , at 118-19.

90. See id. at 120.

91. Id. at 122 .

92. In 1904, only three states retained prohibition laws. By the time the United States entered World War I in 1917, 24 states had prohibition laws. By 1919, prior to the adoption of the amendment, the number had risen to 33 . R. FosDICK \& A. SCOTT, supra note 16 , at 3.

93. The Food and Fuel Control Act, ch. 53, § 15, 40 Stat. 276, 282 (1917) (also known as the Lever Act).

94. Acts of November 21, 1918, ch. 212, § 1(4), 40 Stat. 1045, 1046 (1918) (section 1(4) is known as the War Prohibition Act); see also L. SCHMECKEBIER, supra note 2, at 5.

95. S.J. Res. 17, 40 Stat. 1050 (1917).

96. Amendment to the Constitution of 1919,40 Stat. 1941 (this text was later changed and became the eightecnth amendment).

97. Id. at 1942.

98. Congress passed title I of the Volstead Act to continue the War Prohibition Act until constitutional prohibition took effeet. The Volstead Act, ch. 85, tit. I, 41 Stat. 305 (1919) (also known as The National Prohibition Act), amended in part and repealed in part by The Liquor Law Repeal and Enforcement Act, ch. 740, 49 Stat. 872 (1935); see also Hamilton v. Kentucky Distilleries, 251 U.S. 146, 163 (1919) (upholding the continuation of wartime Prohibition); L. SCHMECKEBIER, supra note 2, at 5-6. The Volstead Act placed primary authority to enforce prohibition with the Commissioner of Internal Revenue. See The Volstead Act, tit. II, §§ 2, 38. This coupling of the two prohibitions prompted a veto from President Wilson. Congress quickly overrode it and the Volstead Act became law. L. SCHMECKEBIER, supra note 2, at 6.

99. Prior to Prohibition, Alabama residents had declared that even though hquor traffic in 


\section{B. Prohibition}

The eighteenth amendment gave states concurrent power with the federal government to enforce the ban on the manufacture, sale, and transportation of alcoholic beverages. ${ }^{100}$ A state could pass legislation enforcing the amendment so long as that legislation did not violate provisions of the Volstead Act. ${ }^{101}$ As the Supreine Court noted in McCormick \& Co. v. Brown: ${ }^{102}$ "While state legislation cannot give validity to acts prohibited by the Eighteenth Amendment, that legislation may provide additional instruments to make the prohibition effective."103 States, therefore, could provide more stringent penalties, but not less stringent penalties.

The federal government, however, took the lead in enforcing Prohibition. This allocation of authority to federal law enforcement officials proved responsible for many of Prohibition's failures. Andrew Mellon, Secretary of the Treasury, adnitted in his annual report for 1926 that states ought to have been the front-line regulators of alcoholic beverages:

[T] he Treasury felt with respect to local law enforcement that too much responsibility had been placed upon the Federal Government. Even in those States which already had satisfactory State laws, and in which local machinery for enforcement had been provided, citizens and officials were looking to the Federal forces for the performance of police duties which were purely local. This misinterpretation of jurisdiction, while perhaps natural and for that reason excusable, proved a serious hindrance to the successful enforceinent of the national prohibition law. Were the Federal Government to aceept this responsibility, it must organize large police forces in the various coinmunities, and, in addition, must provide adequate judicial machinery for the disposition of the local cases-an interference by the Federal Government with local government which could not be other than obnoxious to every right-thinking citizen. ${ }^{104}$

Federal efforts at regulating alcoholic beverages failed during Prohibition. Even when federal efforts were focused on a particulan concern-for example, the smugghing of whiskey into the United States from

their state was "as dead as the men who lived before the flood," they would never surrender control to the federal government. N. CLARK, supra note 30, at 123-24.

100. U.S. ConsT. amend. XVIII, \& 2 (1919, repealed 1933).

101. Ex parte Ramsey, 265 F. 950,953 (S.D. Fla. 1920); see also United States v. Lanza, 260 U.S. 377, 381 (1922) ("[T] he second section of the Eighteenth Amendment put an end to restrictions upon the State's power arising out of the Federal Constitution and left her free to enact prohibition laws applying to all transactions within her limits.").

102. 286 U.S. 131 (1932).

103. Id. at $143-44$.

104. L. SCHMECKEBIER, supra note 2, at 12 (quoting 1926 SECRETARY of TREAS. ANN. REP. 139-40). 
Canada-the problem persisted. ${ }^{105}$ In fact, according to the United States Attorney General's Report from 1928, “'m the course of three years the volume of [whiskey smuggling from Canada to the United States] has mcreased more than 75 percent."106

While Customs tried to sten the tide of Canadian whiskey, Bureau of Prohibition agents focused on industrial alcohol, the chief source of hard hquor. ${ }^{107}$ These agents could boast of some dramatic busts and huge reductions in bootlegging, ${ }^{108}$ but the large seizures only proved that "alcohol was flowing freely and continuously." 109

Industrial alcohol was particularly problematic because it was poisonous and unfit for human consumption. ${ }^{110}$ The federal government and bootleggers waged battles over industrial alcohol, as the government would denature ${ }^{11}$ and the bootleggers would attempt to re-distill the booze.

To prevent this sort of re-distilling the government tried various formulas for making imdustrial alcohol strictly industrial. They put in stuff that gave it a sickening smell. But the bootleggers hired smart chemists and learned how to get rid of that. The government inade the poison more poisonous. And the bootleggers fixed that. The government even put in kerosene that could not be distilled out and it was distilled out. Finally

105. In 1928, according to the U.S. Attorney General's Office, the problein of liquor smuggling from Canada remained "unsolved." Id. at 16 (quoting 1928 ATT'Y GEN. ANN. REP. 36-37).

106. Exports of Whiskey froin Canada to United States:

Amount in Gallons

\begin{tabular}{|c|c|}
\hline $\begin{array}{l}1925 \\
1926 \\
1927 \\
1928\end{array}$ & 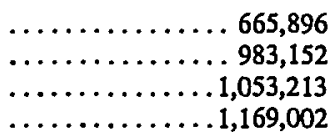 \\
\hline & Canadian Value \\
\hline $\begin{array}{l}1925 \\
1926 \\
1927 \\
1928\end{array}$ & $\begin{array}{l}\ldots \ldots \ldots \text { Can. } \$ 10,772,988 \\
\ldots \ldots \ldots \text { Can. } \$ 15,475,270 \\
\ldots \ldots \ldots \text { Can. } \$ 17,171,484 \\
\ldots \ldots \ldots \text { Can. } \$ 18,883,541\end{array}$ \\
\hline
\end{tabular}

Id. at 17 (quoting 1928 ATT'Y GEN. ANN. REP. 36-37 (figures supplied by the Canadian Departinent of Trade and Coininerce)).

107. Mills, Where the Booze Begins, ColliER's, Oct. 15, 1927, at 9.

108. In 1925, 16 denaturing plants in New York produced about 11 inillion gallons of alcohol a year. Two years later, the quantity of this denaturing liad dropped to less than 500,000 gallons a year. Major Mills, former Prohibition Adıninistrator of the Second Federal District, noted that this difference ineant "that previously some ten million gallons annually was diverted to bootleggers." Id. at 8 .

109. Id.

110. I. Einstein, Prohibition Agent No. 1 222-23 (1932). "[D]enatured alcohol could never be inade really harmless." Mills, supra note 107, at 34. Soine Americans adapted to the poison and, upon tasting pure booze on visits to Canada, they coinplained bitterly about the lack of an authentic kick.

111. To denature alcohol means to inake it unfit for drinking by adding an obnoxious substance, while maintaining its usefulness for soine other purpose. WEBSTER's NEw Collegiate DICTIONARY 303 (1977). 
the government made alcohol muddy-looking and guaranteed against bootlegging. And the bootleggers fixed that too. ${ }^{112}$

Moreover, genuine whiskey for medicinal purpose was often diverted and replaced with "hooch." Druggists therefore could not be sure that even the whiskey that came from bonded warehouses was genuine. ${ }^{113}$

A major cause of the federal government's failure to regulate alcoholic beverages effectively was an agent pool created and fueled by patronage. ${ }^{114}$ Major Mills, a former Prohibition administrator for the Second Federal District, wrote in 1927 that Prohibition was a party spoils systein:

Three quarters of the 2,500 dry agents are ward heelers and sycophants named by the politicians. And the politicians, whether professionally wet or professionally dry, want prohibition because they regard prohibition as they regard postmasterships-a reservoir of jobs for henchmen and of favors for friends.

...

... Prohibition is the new pork barrel. ${ }^{115}$

The patronage system prevailed in every Prohibition district in the country. ${ }^{116}$ As a result, the Prohibition Bureau ended up with few agents exhibiting the Hollywood-produced legendary derring-do of Elliott Ness or the cunning, guile, and sheer buffoonery of Izzy Einstein. ${ }^{117}$ Instead,

112. I. EinsteIN, supra note 110 , at $222-23$ (emphasis in original).

113. Mills, supra note 107, at 32 .

114. The Volstead Act provided that executive officers having "immediate direction of the enforcement of the provisions of this Act, and persons authorized to issue permits, and agents and inspectors in the field service" were exempt from civil service regulations. The Volstead Act, tit. II, $\S 38,41$ Stat. at 319. A 1913 act carried permanent legislation allowing the appointment without civil service examination of deputy collectors of internal revenue and deputy marshals. Act of Oct. 7, 1913, ch. 32, 38 Stat. 208. This Act apphied not only to supervisory personnel, but also to rank and file agents. $I d$.

115. Mills, Dry Rot, Collier's, Sept. 17, 1927, at 48.

116. Id. at 5. The decision to inake prohibition agents political appointees rather than civil service workers illustrates again the pohtical sway of the Anti-Saloon League. The ASL wanted agents to be political appointees, in order to guarantee League involvement in all appointments. This provision was an easy coup for the League since Wayne Wheeler-the league's chief spokesman and perhaps the most powerful nonelected politician in America at that time-had a large part in drafting both the ainendment and the Volstead Act. J. BLOCKER, supra note 34, at 95-97.

117. Einstein headed the Flying Squadron of the Federal Prohibition Bureau's New York district. N.Y. Times, Apr. 2, 1921, at 9, col. 1.

What Izzy brought to prohibition enforcement . . . was the spirit of fun, of buffoonery.

There are a few convinced prohibitionists among the dry agents who conduct raids and lock up bootleggers because their hearts are in the cause-not many, but a few. But this fanatical pleasure is vastly different from the sheer joy experienced by Izzy when, disguised as a musician, a waiter, a drummer, a mill hand or a visiting buyer, he betrayed the evildocrs. He was not bitter against booze, but it was fun to be in the tricky business of catching the violators. He made raids before dawn, wlien he didn't have to. One Sunday he raided seventy-one places!

Walker, Introduction, in I. EINSTEN, supra note 110, at $\mathrm{xx}$-xxi (Walker was the city editor of the New York Herald Tribune). 
the Bureau's staff consisted of agents more inclined to ineptitude and venality. ${ }^{118}$ A federal grand jury for the Southern District of New York investigating a hquor raid excoriated Prohibition Bureau agents, statimg that: "[A]linost without exception the agents are not men of the type of intelligence and character qualified to be charged with this difficult and important duty and Federal law."119 President Harding reported to Congress a few weeks later that "conditions relating to [Prohibition] enforcement ... savor of nationwide scandal. It is the most demoralizing factor in public life." 120

As America soured on Prohibition, the primary force behind repeal becaine the Association Against the Prohibition Amendment (AAPA), a group directed by some of the nation's wealthiest persons. ${ }^{121}$ In maneuvering the passage of the twenty-first amendment, the "AAPA, like the Anti-Saloon League before it, had manipulated the mechanics of non partisan, pressure-group pohtics with consummate skill." 122 The very power achieved by the temperance movement, on the other hand, contributed to its own downfall. Many people concluded that the politics of the dry era were even more corrupt than the pohtics of the saloon era. ${ }^{123}$ Moreover, as the ASL strayed from its earher policy of broad-based reforin, it became vuhierable to its fanatics. ${ }^{124}$ The onset of the Great Depression further soured the public on Prohibition. The people lauded revenues that could be raised through taxation of alcohol as the economic salve the nation needed. ${ }^{125}$ Moreover, the growing ranks of the

118. See N.Y. Times, Nov. 19, 1922, at 1, col. 5 (50 agents dropped from New York office for "not producing satisfactory results"). This New York Times story also reported that state judges had thrown out two prohibition prosecutions. In one case, agents had ordered three rounds of highballs in a cabaret "to be sure it was whisky." Id. In a second case, the judge threw out evidence obtained in a warrantless search. Id. In 1926, there were 2,700 agents, inspectors, and investigators nationwide. Prohibition Unit records reveal, however, that between 1920 and 1926, 752 enforcement officers, agents, and inspectors were fired for delinquency, derehiction of duty, accepting bribes, intoxication, and similar offenses. L. SCHMECKEB1ER, supra note 2, at 51-53.

119. N.Y. Times, Apr. 2, 1921, at 9, col. 1.

120. L. Schmeckebier, supra note 2, at 46 (quoting President Harding's 1922 address to Congress).

121. N. ClARK, supra note 30 , at 200-01. The motivation for the wealthy in supporting repeal was to combat the increased power of the federal government, as well as to offset the higher taxes imposed on the wealthy from the loss of liquor revenue. J. BLOCKER, supra note 34, at 120-21.

122. N. ClaRK, supra note 30, at 207.

123. Id. at 197-98.

In some states, the Anti-Saloon League had disciplined legislatures in quite the same way that the old saloon barons had done before 1916. Political and judicial appointments had been handled with the same expediency. The Prohibition Bureau itself had been a plush system of political patronage for the ASL and its friends, and it was painfully clear that special interests were privileged to use public agencies for their own political purposes.

Id.

124. One of the most fanatical prolibitionists was Henry Ford, who announced in 1929 that, were the eighteenth amendment repealed, he would cease automobile production and refuse to pay workers wages "which the saloons would take away from them." Id. at 198.

125. Id. at 200. 
unemployed resented the salaries the revenue agents received. ${ }^{126}$ These two factors swung the consensus of public opinion toward the repeal of the eighteentli amendment.

It was this dismal experience with prohibition under federal control that contributed to sentiment both in Congress and in the states to insist on state control of liquor upon repeal.

\section{Repeal}

The dawn of repeal inet with universal celebration. In addition to the states' enthusiasm at regaining local control of liquor laws, ${ }^{127}$ Congress rallied behind repeal. The central question, lowever, remained what post-prohibition regulation would look like. As originally proposed, the twenty-first amendment contained four sections. The first repealed the eigliteentli amendinent, and the fourth provided for ratification by the states. ${ }^{128}$ The debate centered on sections two and three.

Section three gave Congress concurrent power to regulate the sale of alcohol for consuniption on the premises. ${ }^{129}$ This provision particularly concerned some members of Congress because it preserved a federal role in local liquor enforcement. ${ }^{130}$ In fact, some believed that section three defeated the entire purpose of repeal. ${ }^{131}$ Congress eventually voted to delete section three, ostensibly preserving the in-state control of intoxicating hiquor for the states theinselves.

Section two, however, continued to prompt a deep division in interpretation of the amendment. Section two provides that the "transporta-

126. Id.

127. See, eg., Ratification of THE TWENTY-FIRST AMENDMENT to THE CONSTITUTION OF THE UNITED STATES: State Convention ReCordS AND LAws 60-61 (Connecticut convention), 69-71 (Florida convention), 173-75 (Kentucky convention), 412 (Utah convention) (E. Brown ed. 1938) [hereinafter CONVENTION RECORDS].

128. S.J. Res. 211, 72d Cong., 2d Sess., 76 Cong. REC. 4138, 4139 (1933). The original proposal read:

Section 1. The eightecnth articlc of amendment to the Constitution of the United States is hereby repealed.

Sec. 2. The transportation or importation into any State, Territory, or possession of the United States for delivery or use therein of intoxicating hiquors, in violation of the laws thereof, is hereby prohibited.

Sec. 3. Congress shall have concurrent power to regulate or prohibit the sale of intoxicating liquors to be drunk on the premises where sold.

Sec. 4 This article shall be inoperative unless it shall have been ratified as an amendment to the Constitution by the legislatures of the several States, as provided in the Constitution, within seven years front the date of the subnission hereof to the States by the Congress.

129. Id.

130. "If the Federal Government failed to discharge that responsibility under the all-embracing prohibition of the eighteenth amendment, what folly is it which prompts anyone to believe that it can discharge it under the nilder language of the pending resolution." 76 CONG. REc. 4145 (1933) (remarks of Sen. Wagner).

131. See id. at 4143 (remarks of Sen. Wagner) (in the event of a conflict between state and federal law, federal law would prevail, and therefore the word concurrent is mcaningless). 
tion or importation into any State, Territory, or possession of the United States for dehvery or use therein of intoxicating liquors, in violation of the laws thereof, is hereby prohibited."132 What Congress intended by this language is incapable of precise divination. Actual debate in Congress was ambiguous, ${ }^{133}$ and the ratification conventions prompted no discussion. ${ }^{134}$

Two interpretations have ennerged. The "federalist"135 view was that section two inerely protected dry states: that is, states that allowed the inportation, inanufacture, or sale of intoxicating liquor gained no new powers vis-à-vis the federal government under the amendinent. The "absolutists" beheved that the section gave states plenary power to regulate the evils associated with intoxicating beverages. ${ }^{136}$

Federahists argued that the section simply constitutionalized the Webb-Kenyon Act's protections for dry states from the influx of liquor from wet states and in no way detracted from Congress' power to regulate interstate commerce. This argument lias some support in the Senate debates. Since the Webb-Kenyon Act's constitutionality was challenged by the President and the Attorney General ${ }^{137}$ and was validated only by a divided Supreine Court, ${ }^{138}$ soine in Congress felt the Act needed a little constitutional inortar. Senator Blaine reinarked:

There has been a divided opinion in respect to the earlier cases [over the constitutionality of the Webb-Kenyon Act], and that division of opinion seems to have come down to a very late day. So, to assure the so-called dry States against the importation of imtoxicating hiquor into those States, it is proposed to write permanently into the Constitution a prohibition along that line. ${ }^{139}$

Absolutists, on the otler liand, believed that the twenty-first amendnent vested coinplete control over intoxicating liquor in the states. The absolutist argument is premised on the deletion of the proposed section three of the amendment, which would have given the federal government concurrent power to regulate alcohol. ${ }^{140}$ The statements of several sena-

132. U.S. CONST. amend. XXI, $\$ 2$.

133. See infra notes $139-42$ and accompanying text.

134. CONVENTION ReCORDS, supra note 127, at 6-7; Note, Economic Localism in State Alcoholic Beverage Laws-Experience Under the Twenty-First Amendment, 72 HARv. L. REv. 1145, 1147 (1959).

135. The terms absolutist and federalist are culled from Note, Federal District Court Exempts Interstate Rail Carrier From State Open Saloon Prohibition, 6 CREIGHTON L. REv. 249, 252-53 (1972) (authored by Michael E. Loomis).

136. Comment, The Effect of the Twenty-First Amendment on State Authority to Control Intoxicating Liquors, 75 COLUM. L. REv. 1578, 1579 (1975) (authored by David S. Versfelt).

137. See supra notes 83-86 and accompanying text.

138. Justice McReynolds concurred in the result and Justices Holmes and Van Devanter dissented. Clark Distilling Co. v. Western Md. Ry., 242 U.S. 311,332 (1917).

139. 76 CONG. REC. 4141 (1933).

140. See supra notes $129-31$ and accompanying text. 
tors also support an absolutist interpretation. In urging the Senate to delete the proposed section three to the amendment, Senator Wagner said:

It must be left to the States; and I believe the overwhelming sentiment in this country is so definite in every State that we will have no return of the saloon.... [L]et the people of each State deal with that subject, and they will do it more effectively and inore successfully than the Federal Government has done because it is not the business of the Federal Government. ${ }^{141}$

The plain language of section two further supports the absolutists. Section two completely bars the "transportation or importation into any State, Territory, or possession of the United States" intoxicating liquors in violation of that state's laws. ${ }^{142}$ The section lacks any mention of concurrent federal power.

A second disagreement that arises under the absolutist position is whether the twenty-first amendment acts merely to override provisions of the dormant commerce clause, or whether it empowers states to override all federal constitutional and statutory constraints in the nane of hquor control. ${ }^{143}$ While early twenty-first amendment cases held that the amendment could not be confined by the fourteenth amendment or other constitutional provisions, ${ }^{144}$ dicta in more recent cases implies that it should be read no nore broadly than to act as a limitation on the dor-

141. 76 CONG. REC. 4146 (1933).

142. U.S. CONST. amend XXI, $\S 2$.

143. The extent to which the twenty-first amendment may grant states power to override other constitutional provisions, particularly those securing personal liberties, is beyond the scope of this Comment. Some cases that have analyzed conflicts between the twenty-first amendment and personal constitutional guarantees are histed below.

Equal Protection Clause: Craig v. Boren, 429 U.S. 190, 199-210 (1976) (statute allowing beer sales to women but not men violated equal protection clause); Goesaert v. Cleary, 335 U.S. 464 (1948) (upholding statute barring a woman from being a bartender unless she is the owner or wife of the owner of the bar); Women's Liberation Union of R.I. v. Israel, 379 F. Supp. 44,47 (D.R.I. 1974) (twenty-first amendment does not supersede equal protection clause), aff'd, 512 F.2d 106 (1st Cir. 1975); Daugherty v. Daley, 370 F. Supp. 338, 340 (N.D. Ill. 1974) (no rational basis for statute that distinguished between male and female enployees in forbidding women from soliciting drinks in bars); Baxley v. Potts, 337 F. Supp. 7, 9 (M.D. Ala. 1972) (upholding statute that forbids sale of draft beer except in rural areas of "predominantly foreigu populations" among whom the consumption of the beer is customary); United States v. Cantrell, 307 F. Supp. 259, 264 (E.D. La. 1969) (no rational basis for statute barring servicemembers in uniform from bars when purpose of statute was to bar blacks); Sail'er Inn v. Kirby, 5 Cal. 3d 1, 21-22, 485 P.2d 529, 542-43, 95 Cal. Rptr. 329, 342-43 (1971) (rejecting Goesaert-type statute).

Due Process Clause: Wisconsin v. Constantineau, 400 U.S. 433, 439 (1971) (striking down statute that enabled designated persons to prohibit sale of liquor to certain individuals witlout affording the person a hearing).

First Amendment: City of Newport v. Jacobucci, 479 U.S. 92, 94-95 (1986) (per curiain) (city can ban topless dancing in bars); New York State Liquor Auth. v. Bellanca, 452 U.S. 714, 717 (1981) (per curiam) (state can ban topless dancing in bars); California v. LaRue, 409 U.S. 109, 115 (1972) (upholding statute barring performance of certain sexual acts in liquor establishments).

144. See infra notes 151-55 and accoinpanying text. 
mant commerce clause. ${ }^{145}$

In its first decision on the twenty-first amendment, the Supreme Court sided with the absolutists, relying on the plain language of the amendment. ${ }^{146}$ State Board of Equalization v. Young's Market Co. ${ }^{147}$ involved a California statute that imposed a 500-dollar import hicense fee on beer importers, but imposed no such fee for domestic beers. Upholding the statute, Justice Brandeis concluded that the twenty-first amendment empowered wet and dry states alike to regulate the importation, manufacture, and sale of hquors. ${ }^{148}$ Moreover, the Court concluded that discriminatory regulations were permissible. ${ }^{149}$

Young's Market took the broadest view of the twenty-first amendment. Not only did it embrace the absolutist position that the amendment was inore than a protection for dry states, but also it intimated that the amendment was much more than a limitation on the dormant commerce clause. The Court wrote that if a classification was permissible under the twenty-first amendment, it could not be invalidated under the fourteenth ainendment. ${ }^{150}$

The Court's broad interpretation of twenty-first ainendment powers continued through some early cases in which the Court upheld blatantly discriminatory statutes. In Mahoney v. Joseph Triner Corp., ${ }^{151}$ the Court upheld a Minnesota statute that banned the importation of liquors containing more than twenty-five percent alcohol unless the brand was registered with the U.S. Patent Office. The Court held that discrimination against imported hquor was permissible even if it was not "an mcident of reasonable regulation of liquor traffic."152 The following year, the Court upheld a Michigan statute that barred liquor dealers from selling any beer manufactured in a state which, by its laws, discriminated against Michigan beer. ${ }^{153}$ The Court ruled that neither the federal commerce clause, the equal protection clause, nor the due process clause limited a state's right to regulate hquor importation. ${ }^{154}$

In the companion case of Joseph S. Finch \& Co. v. McKittrick, ${ }^{155}$ the

145. See infra notes $168-76$ and accompanying text.

146. State Bd. of Equalization v. Young's Mkt. Co., 299 U.S. 59, 63-64 (1936) ("As we think the language of the Amendment is clear, we do not discuss these matters.").

147. 299 U.S. 59 (1936).

148. Id. at $62-63$.

149. Id. at 63 ("[S]urely the State may adopt a lesser degree of regulation than total prohibition.").

150. Id. at 64 . But see supra note 143 (citing various other cases interpreting conflicts between the twenty-first and other amendments).

151. 304 U.S. 401 (1938).

152. Id. at 403 (citing Young's Market, 299 U.S. at 62-63).

153. Indianapolis Brewing Co. v. Liquor Control Comm'n, 305 U.S. 391 (1939).

154. Id. at 394

155. 305 U.S. 395 (1939). 
Court similarly ruled that the commerce clause did not limit the right of states to regulate the importation of liquor. ${ }^{156}$ Finally, in Ziffrin, Inc. $v$. Reeves, ${ }^{157}$ the Court uplield a compreliensive, 123 -section Kentucky statute that rigidly regulated virtually every phase of liquor transportation and distribution. ${ }^{158}$ The statute declared illegal every phase of liquor trafficking that was not expressly allowed. ${ }^{159}$ The Court maintained its broad reading of the amendment, concluding that " $[t]$ he State may protect lier people against evil incident to intoxicants and may exercise large discretion as to means employed." 160

Ziffrin, however, contamed the seeds of the Court's retreat from this broad imterpretation. The Court spoke of a state's power in broad language, but at the saine time appeared to apply a reasonableness test to the Kentucky regulations. ${ }^{161}$

State regulation suffered a less ainbiguous setback in an early case, Collins v. Yosemite Park \& Curry Co. ${ }^{162}$ In Collins, the state of California attempted to impose fees and taxes on liquor sales in Yosemite National Park. The Court upheld the riglit of the state to impose an excise tax on sales because the state reserved that right when it ceded. park land to the federal government. ${ }^{163}$ The Court struck down the regulatory provisions of the statute, however, dismissing the twenty-first amendment defense. Since the federal government exercised exclusive jurisdiction over the park, the state's twenty-first annendment powers were void because "[t]liere was no transportation into California 'for delivery or use therem." "164 Where the federal government held exclusive jurisdiction over a territory, the state's powers under the twenty-first amendment were not applicable. ${ }^{165}$

The Court later interpreted the Collins decision as holding that, while the twenty-first amendment relieves the states of commerce clause limitations, "shipment through a state is not transportation or importation into the state within the meaning of the Amendment."166 Nevertheless, the Court lias maintained that this reading of the twenty-first

156. Id. at 398.

157. 308 U.S. 132 (1939).

158. Id. at 134 .

159. Id.

160. Id. at 138-39 (citations omitted).

161. Kentucky has seen fit to permit manufacture of whiskey only upon condition that it be sold to an indicated class of customers and transported in definitely specified ways. These conditions are not unreasonable and are clearly appropriate for effectuating the policy of limiting traffic in order to minimize well-known evils, and secure payment of revenue.

Id. at 139 (emphasis added).

162. 304 U.S. 518 (1938).

163. Id. at 532-33.

164. Id. at 538 (quoting U.S. CONST. amend. XXI, § 2).

165. Id. at 538 .

166. Carter v. Virginia, 321 U.S. 131, 137 (1944). 
amendment does not diminish a state's right to regulate the throughshipinent of hquor in order to prevent its diversion into state commerce. ${ }^{167}$

The Court cut back further on state control over intoxicating liquors in United States v. Frankfort Distilleries. ${ }^{168}$ In upholding the indictment of several producers, wholesalers, and retailers for violating the Sherman Antitrust Act, the Court dismissed a claim that the twenty-first amendment barred the prosecution. The Court held that granting states full authority to regulate alcohol within their borders does not give them "plenary and exclusive power to regulate the conduct of persons doing an interstate hquor business outside their boundaries." 169 Nor does it follow, the Court wrote, that the U.S. government is without power to regulate the interstate flow of hiquor. ${ }^{170}$ A year later, in Nippert $v$. City of Richmond, ${ }^{171}$ the Court asserted that even though the twenty-first amendment gives states the highest degree of control over commerce in liquor, that power is not altogether beyond the reach of the federal coinmerce power-at least not when the state's regulation squarely conflicts with laws imposed by Congress to govern interstate trade or traffic. ${ }^{172}$

The Court consummated its full retreat from earlier broad readings of twenty-first amendment power, in a pair of decisions handed down in 1964: Hostetter v. Idlewild Bon Voyage Liquor Corp. ${ }^{173}$ and Department of Revenue v. James B. Beam Distilling Co. ${ }^{174}$ Instead of the full deference afforded state statutes regulating hquor, the Court established that when a state statute conflicts with federal law, the two laws must be accommodated. ${ }^{175}$ The Court rejected as an "absurd oversimplification" and as "deinonstrably incorrect" the assertion that the twenty-first amendment "repealed" the commerce clause as it related to hquor. ${ }^{176}$

Hostetter and James Beam established the modern accommodation

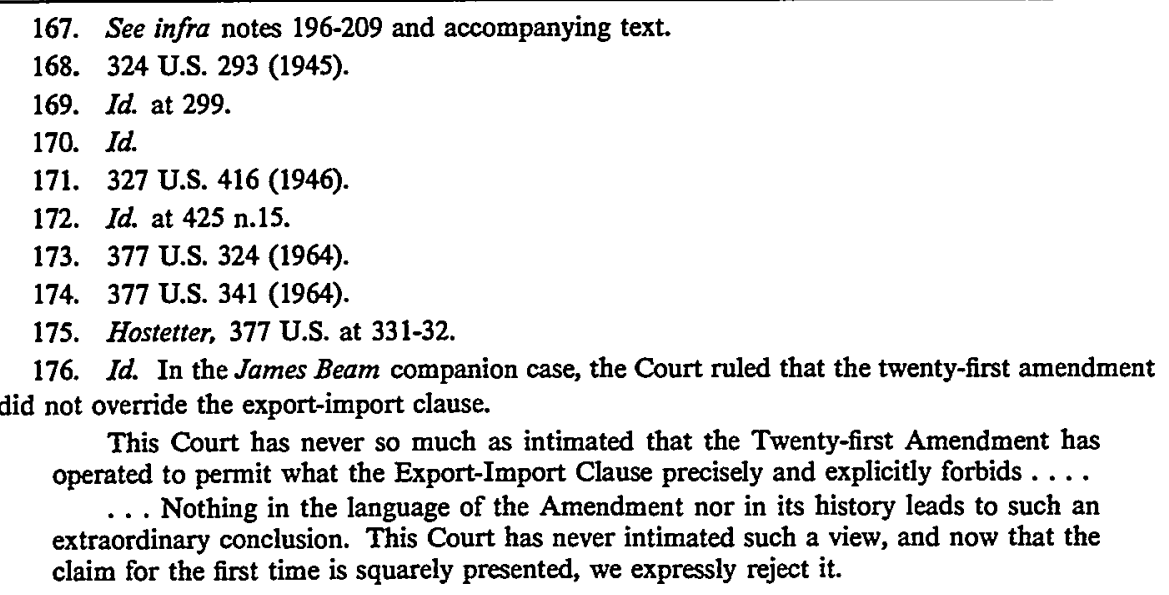
377 U.S. at $344-46$. 
standard. Subsequent cases purport to use this standard to balance federal and state control over the regulation of intoxicating liquor.

II

\section{A Three-Part Accommodation Test}

Even as the Court began carving back state powers under the twenty-first amendinent, it continued to recognize that it ought to give deference to state statutes passed under the amendinent's core power. Since the 1964 decisions of Hostetter and James Beam, the Court has only loosely defined the contours of its accommodation test. It has used the most fervent language to protect hiquor statutes passed under the twenty-first amendment, but in recent years, these promises have rung hollow. This new adaption of the accommodation test culminated in two recent decisions ${ }^{177}$ where the Court verbally deferred to core power regulations, but nonetheless subjected them to exacting scrutiny. In these two recent decisions, the Court has come perilously close to treating liquor as an ordinary article of commerce, "just like peanuts and potatoes"178 and "cabbages and candlesticks."179

\section{A. The Three-Part Accommodation Analysis}

The accommodation requirement established in Hostetter would best be articulated in a three-step analysis. Although the Court itself has not yet articulated an explicit analytical device, this proposed three-step test can be derived from a review of their cases. The main purpose of the test is to protect state power over hquor, while preventing state attempts to overreach. The test upholds local control over liquor, which has proven to be the only effective system of regulation. The analysis simultaneously protects individual and federal interests against statutes targeted at improper purposes.

The mitial question in this proposed analysis can be dispositive: Does the state statute conflict with federal law? Where no conflict arises, the statute is a valid exercise of twenty-first amendment power. The supremacy clause creates no constraint. ${ }^{180}$

If the statute conflicts with federal law, however, the court must determine whether the state law was promulgated under a state's core

177. North Dakota v. United States, 110 S. Ct. 1986 (1990); 324 Liquor Corp. v. Duffy, 479 U.S. 335 (1987).

178. United States v. Frankfort Distilleries, 324 U.S. 293, 300 (1945) (Frankfurter, J., concurring).

179. Carter v. Virginia, 321 U.S. 131, 139 (1944) (Frankfurter, J., concurring).

180. See Capital Cities Cable v. Crisp, 467 U.S. 691, 698 (1984) (In holding that the Federal Communication Commission preempted an Oklahoma statute banning liquor advertisements, the Court considered first "whether the Oklahoma statute [did] in fact conflict with federal law."). 
twenty-first amendment power. As the Supreme Court noted in California Retail Liquor Dealers Association v. Midcal Aluminum, Inc., ${ }^{181}$ the twenty-first amendment grants the states "virtually complete control over whether to permit importation or sale of hquor and how to structure the hquor distribution system."182 Only when a state has not attempted to regulate the sale or use of hiquor within its border may a conflicting federal authority prevail. ${ }^{183}$

This second prong focuses on "whether the interests imphicated by a state regulation are so closely related to the powers reserved by the Twenty-first Amendinent that the regulation may prevail, notwithstanding that its requirements directly conflict with express federal pohcies."184 This inquiry is purpose-based. If the court finds that the purpose of the statute was to regulate the consumption, importation, manufacture, or transportation of hquor, the law must prevail unless it bears no rational relationship to its imtended purpose. ${ }^{185}$

If a state statute is found to have been promulgated on grounds other than core twenty-first amendment powers, the court should apply a traditional preemption analysis, since the special constitutional interest of the state in enacting the law-the core hquor power-is no longer present. The threshold question in a preemption analysis is jurisdictional: whether the subject inatter is in the exclusive domain of the federal government. ${ }^{186}$ If so, there are two bases for finding preeinption.

First, when Congress intends that federal law occupy a given field, state law in that field is preempted. Second, even if Congress has not occupied the field, state law is nevertheless preempted to the extent it actually conflicts with federal law, that is, when compliance witl both state and federal law is impossible, or when the state law stands as an obstacle to the accomphishment and execution of the full purposes and objectives of Congress. ${ }^{187}$

When the issue falls outside these areas of congressional plenary power, the traditional preemption analysis requires a balancing of state and federal interests. Primary considerations in this balancing inquiry include: (1) the pervasiveness of the federal regulatory scheme; (2) the extent of need for national umiformity of law; (3) the dangers of a conflict

181. 445 U.S. 97 (1980).

182. Id. at 110 .

183. Crisp, 467 U.S. at 715 :

[A]lthough a state regulatory scheme obviously need not amount to a comprehensive attack on the problems of alcohol consumption in order to constitute a valid exercise of state power under the Twenty-first Amendment, the selective approach Oklahoma has taken toward liquor advertising suggests limits on the substantiality of interests it asserts here ...."

184. Id. at 714.

185. Id.; see infra notes 189-223 and accompanying text (discussing the purpose analysis).

186. United States v. Texas, 695 F.2d 136, 138 (5th Cir.), cert. denied, 464 U.S. 933 (1983).

187. California v. ARC Am. Corp., 109 S. Ct. 1661, 1665 (1989) (citations omitted). 
between state laws and the administration of federal programs; and (4) the degree of state law infringement upon individual constitutional liberties. ${ }^{188}$

A workable accommodation analysis will protect botli state and federal interests. This Comment's proposed three-part test protects federal interests against potential state overreaching by invalidating state laws issuing froin authority outside the state's core twenty-first ainendment power. At the same time, the test protects state interests by freeing the states to pursue liquor regulation for proper purposes. As long as the court can determine whether a statute was promulgated witlin the state's core power, the test will be effective. It is to this inquiry we now turn.

\section{B. Establishing a Purpose-Based Distinction}

The lieart of the Hostetter accommodation test is the second prong, determining whether the regulation falls within the state's core power under the twenty-first ainendinent. The Court has adopted a purposebased test to make this determination. Understanding low the accommodation test operates to protect state and federal interests requires some familiarity with the purpose-based distinction, for this purposebased distmction is the Court's only ineans to secure state power over liquor under the twenty-first ainendment. ${ }^{189}$ The development of the Court's accommodation test illustrates how the purpose-based distinction lias evolved into a workable frainework for evaluating liquor regulations.

In addition to ferreting out state overreaching under twenty-first ainendment regulation, the purpose-based distinction reconciles seemingly contradictory decisions tliat the present Court lias liad difficulty liarmonizing. ${ }^{190}$ Altliough no simple solution determines what purposes

188. Texas, 695 F.2d at 138-39.

189. This Comment agrees with the Court's movement away from early decisions that implied blanket twenty-first amendment superiority over individual constitutional protections. See supra notes 143, 150-76 and accompanying text. The problems associated with state abuse of twenty-first amendment authority is precisely the reason courts have undertaken the purpose-based inquiry. See, e.g., California Retail Liquor Dealers Ass'n v. Midcal Aluminum, Inc., 445 U.S. 97, 110 (1980) (state control over liquor varies according to the statute's purpose).

190. Compare Justice Scalia's concurring opinion with Justice Brennan's dissent in North Dakota v. Umited States, 110 S. Ct. 1986 (1990). Scalia argued that United States v. Mississippi Tax Commission, 421 U.S. 599 (1973), merely concluded that states were not empowered to tax the federal government under the twenty-first amendment, and were not necessarily barred from imposing regulations on federal entities. North Dakota, $110 \mathrm{~S}$. Ct. at 2001 (Scalia, J., concurring). Brennan argued that the Mississippi Tax decision should not be read too narrowly, and should be extended to bar state regulation of the federal government. Id. at 2011-12 (Brennan, J., dissenting). A purpose-based distinction would solve the confiict. Since Mississippi's purpose in taxing liquor sold on federal military bases was to raise money, the statute falls outside the statc's core twenty-first amendment power and would be subject to conventional preemption analysis. If a state's purpose is to control the distribution of liquor, the regulation would be afforded more deference. 
are within a state's core power, the language of the text is a good beginning. The amendment specifically empowers states to regulate transportation and importation. Moreover, states have long been able to regulate consumption, manufacture, and sale under their pohice power.

Despite rapid narrowing of permissible state liquor regulation, the Court has reaffirmed that statutes specifically targeted at consumption, importation, or distribution of hquor are protected by the twenty-first amendinent. For example, the Court ruled in Hostetter v. Idlewild Bon Voyage Liquor Corp. ${ }^{191}$ that an airport hquor store (regulated by the U.S. Customs Service) that sold alcohol to departing passengers at John F. Keunedy Airport in New York could not be shut down by the state for noncompliance witli state liquor laws. The Court ruled tliat since Idlewild accepted orders only from departing passengers and the alcohol was delivered directly to the aircraft rather than the passenger, the state was not attempting to prevent the unlawful diversion of alcohol imto interstate commerce. ${ }^{192}$ Therefore, the state regulations were an undue infringeinent of Congress' power under the commerce clause. ${ }^{193}$

Nevertlieless, the Court recognized the importance of protecting a state's core power under the amendinent. The Court wrote that, as in Collins v. Yosemite Park \& Curry Co., ${ }^{194}$ the state would liave been constitutionally permitted to regulate the transportation of liquor from the time of its entry imto the state until its lawful dehivery at the federal enclave. ${ }^{195}$

This deference to core power regulation is consistent with preHostetter cases. In Johnson v. Yellow Cab Transit Co., ${ }^{196}$ the Court invalidated the seizure of alcoliol that was being transported to a military base in Oklahoma. Since the base was a federal enclave, the state could not seize the alcohol: the alcohol was not to be sold, dehivered, or otherwise disposed of in Oklahoma proper. ${ }^{197}$ The Court noted, however, that Oklahoina liad a right to prevent diversion of the alcoliol into state cominerce. "Were this statute intended to do no more than provide a means

191. 377 U.S. 324 (1964).

192. Id. at 325,333 .

193. To draw a conclusion ... that the Twenty-first Amendment has somehow operated to "repeal" the Commerce Clause wherever regulation of intoxicating liquors is concerned would ... be an absurd oversimplification. If the Commerce Clause had been pro tanto "repealed," then Congress would be left with no regulatory power over interstate or foreign commerce in intoxicating liquor. Such a conclusion would be patently bizarre and is demonstrably incorrect.

Id. at 331-32.

194. 304 U.S. 518 (1938).

195. Hostetter, 377 U.S. at 333.

196. 321 U.S. 383 (1944).

197. Id. at 386. Oklahoma law made it unlawful "to import, bring, transport, or cause to be brought or transported into the State ... intoxicating hiquor ... without a permit." OrLA. STAT. tit. $37, \S 41$ (1941). 
whereby the state could protect itself from illegal liquor diversions within the area which Oklahoma has power to govern, the interpretation asked might well be an acceptable one."198

Decisions after Hostetter clarify the contours of the purpose-based distimction. In Bacchus Imports, Ltd. v. Dias, ${ }^{199}$ the Court struck down Hawain statutes that levied a twenty-percent wholesale excise tax on hiquor but exempted certain liquors produced in the state. ${ }^{200}$ In ruling that the state interest in the regulation-economic protection of domestic industry-was not "so closely related to the powers reserved by the Twenty-first Amendment" as to prevail against the commerce clause, the court wrote: "State laws that constitute mere economic protectionism are therefore not entitled to the same deference as laws enacted to combat the perceived evils of an unrestricted traffic in liquor."201

In Craig v. Boren, ${ }^{202}$ the Court struck down on equal protection grounds an Oklahoma statute that permitted women to purchase lowalcohol beer upon reaching their eighteenth birtliday, while males were precluded from buymg low-alcohol beer until they reaclied the age of twenty-one. The Court stated that the relevance of the twenty-first amendment im limiting personal hiberties guaranteed by the Constitution was "increasingly doubtful," but reiterated its deference to liquor regulations passed under a "transparently clear" core purpose. ${ }^{203}$

The Court cemented this purpose-based distinction in two cases lianded down in the 1980s. In California Retail Liquor Dealers Association v. Midcal Aluminum, Inc., ${ }^{204}$ a California statute required all wime producers to sell wine at the same price to all retailers in a trading area. A producer who sold below the establislied price faced fines, hicense suspensions, or license revocation. The defendant, Midcal Aluminum, a wholesale distributor of wine, was charged witl selling twentyseven cases of wime at prices below those set by the price schedule of a wine maker, E \& J Gallo. ${ }^{205}$ The Cahifornia Court of Appeal ruled that the statute violated the Sherman Antitrust $\mathrm{Act}^{206}$ and the California Supreme Court denied review. ${ }^{207}$ The United States Supreme Court

198. Johnson, 321 U.S. at 386 (citing Duckworth v. Arkansas, 314 U.S. 390 (1941) and Carter v. Virginia, 321 U.S. 131 (1944)).

199. 468 U.S. 263 (1984).

200. Id. at 265 . The liquors exempted were pineapple wine and Okoleliao, a brandy distilled from the indigenous ti plant. Id.

201. Id. at 275-76.

202. 429 U.S. 190 (1976).

203. Id. at 206-07.

204. 445 U.S. 97 (1980).

205. Id. at 100 .

206. Midcal Aluminum, Inc. v. Rice, 90 Cal. App. 3d 979, 984, 153 Cal. Rptr. 757, 761 (1979)

(citing 15 U.S.C. $\$ 1$ et seq.).

207. Midcal, 445 U.S. at 102. 
agreed that the statute violated the Sherman Act and that the state's powers under the twenty-first amendment were not broad enough to save the statute. ${ }^{208}$ In invalidating the statute, the Court addressed the importance of assessing the purpose behind California's statute:

The Twenty-first Amendment grants the States virtually complete controk over whether to permit importation or sale of hiquor and how to structure the hiquor distribution system. Although States retain substantial discretion to estabhish other hiquor regulations, those controls may be subject to the federal commerce power in appropriate situations. The competing state and federal interests can be reconciled only after careful scrutiny of those concerns im a "concrete case."209

The Court refined its definition of core powers imder the twenty-first amendment in Capital Cities Cable v. Crisp. ${ }^{210}$ An Oklahoma statute prohibited advertisements for alcohohic beverages except for heavily regulated, on-premise signs. As part of its enforcenent of this provision, Oklahoma barred television broadcasters froin airing alcoholic beverage commercials and required stations to block all such advertiseinents beamed in on network programming. In concluding that the statute was preeinpted by federal communications law, the Court rejected a twentyfirst ainendment defense of the statute. ${ }^{211}$ The Court wrote that "when a state has not attempted directly to regulate the sale or use of hiquor within its borders - the core Section 2 power-a conflicting. exercise of federal authority inay prevail." 212 "[T] is essentially ... whether the interests implicated by a state regulation are so closely related to the powers reserved by the Twenty-first Amendment that the regulation may prevail, notwithstanding that its requirements directly conflict with express federal poicicies."213

By drawing a bright-line rule between core power regulations and other liquor regulations, the Court fashioned a workable balance between state and federal concerns. The Court affirmed states' core power under the annendinent by giving thein "virtually complete control" over the importation and sale of liquor, as well as over the structuring of the distribution system. At the same time, the Court recognized that regulations promulgated for other reasons share none of the same historical precedents for state control under the twenty-first amendment and, thus, should not share the same judicial deference.

Comparing the results in two sets of similar cases will illustrate the

208. Id. at 114.

209. Id. at 110 (citing Hostetter v. Idlewild Bon Voyage Liquor Corp., 377 U.S. 324, 332 (1964)).

210. 467 U.S. 691 (1984).

211. Id. at 716 .

212. Id. at 713 .

213. Id. at 714 . 
adaptability and flexibility of the purpose-based test. Each set of cases represents an instance where a regulation that was passed for a proper purpose survived scrutiny, while a nearly identical statute whose purpose was outside the core powers was struck down.

For instance, in Hostetter, ${ }^{214}$ the Supreine Court struck down state laws that attempted to regulate liquor sold to departing airline passengers, packed directly aboard the plane and kept from passengers until their arrival overseas. ${ }^{215}$ The Court considered the statute outside the state's core power because the liquor would not be consuined in the state. On the other hand, in House of York, Ltd. v. Ring, ${ }^{216}$ a federal district court upheld the licensing, taxation, and other regulatory requireinents against a Connecticut-based mail-order hquor dealer who took inail orders from New York residents, filled the orders with liquor imported froin Europe, and dehvered the hquor by truck to the New York residents. ${ }^{217}$ While acknowledging that the twenty-first ainendinent did not abrogate the commerce clause, the court ruled that states have wide latitude in regulating hquors commg into the state. ${ }^{218}$

The second set of cases concern AMTRAK railway. Both Kansas and Oklahoina had statutory or constitutional provisions forbidding the sale of liquor by the drink for consuinption on the preinises. AMTRAK operated passenger rail lines through both states and served drinks to passengers in lounge cars aboard the trains as they passed through the states. Officials froin both states boarded AMTRAK trains and arrested various einployees for violating state hquor laws.

The federal district court in Kansas upheld the arrests against a commerce clause challenge, ${ }^{219}$ recognizing that states have significant power to regulate hquor when intended for use within the state. The court reasoned that, while a state could not prohibit the transportation of hquor through the state to another destination, the twenty-first ainendment enabled it to impose restrictions on the interstate transit of liquor through such ineans as designating routes of travel or requiring bonding and permits. ${ }^{220}$ Moreover, when the hquor in transit through the state was diverted to a use that contravened state law, the "imitial character of the shipinent [did] not clothe those in possession with iminunity froin prescribed penalties."221

214. Hostetter v. Idlewild Bon Voyage Liquor Corp., 377 U.S. 324 (1964).

215. Id. at $325,334$.

216. 322 F. Supp. 530 (S.D.N.Y. 1970).

217. Id. at 531,536 .

218. Id. at 535 .

219. National R.R. Passenger Corp. v. Miller, 358 F. Supp. 1321, 1328 (D. Kan.), aff'd, 414

U.S. 948 (1973).

220. Id. at 1330 .

221. Id. at 1326 . 
In contrast to the Kansas decision, the federal district court in Oklahoma struck down the statute. While the decision was vacated on the grounds that the plaintiff had not inet the requirements for an mjunction, ${ }^{222}$ the opinion is useful to demonstrate the use of an appropriate accommodation test to protect against state overreaching. In the Oklahoma case, the court found that the state had made no sincere effort to enforce the anti-saloon act. Not only could numerous private establishinents serve liquor by the drink without having the state enforce the law, the court found that "liquor [was] even sold by the drink in three State owned resort lodges."223 The court ruled that "AMTRAK was simgled out" and the "arrest and confiscation was a political stunt with political overtones."224 The decision slows that it is possible to uphold state regulations aimed at preventing diversion of hiquor while at the same tine protecting federal and individual interests by striking down laws whose true purposes are outside the core concerns of the twentyfirst ainendment.

\section{III \\ The Faulty Application}

Although the Supreme Court repeatedly has articulated a purposebased accommodation analysis that deferentially reviews core-power statutes, in recent years the Court has been reluctant actually to apply this test. Instead, the Court increasingly has balanced state and federal interests implicated by a statute, even though the state passed the statute for a core purpose. As a result, the Court has applied heightened scrutiny to these core-power statutes, bleeding life froin the twenty-first amendment and paymg only lip service to the local control that is so important to maintaining functional limits on the distribution and consumption of hquor.

\section{A. The Price-Restraint Cases}

It is possible to trace the Court's weakening of the deference afforded state statutes through its about-face in the treatinent of economic protection regulations. While this reversal is understandable since the purported liquor regulations were clearly outside the scope of the core power, the Court's retreat from deference to all liquor regulationscore power or not-is not so easily justified.

222. National R.R. Passenger Corp. v. Harris, 354 F. Supp. 887 (W.D. Okla. 1972), vacated, 490 F.2d 572 (10th Cir. 1974). The Tenth Circuit vacated the injunction on the grounds that the plaintiff had not shown irreparable injury or invidious discrimination-the prerequisites for a federal injunction of enforcement of a state statute. 490 F.2d at 573-74.

223. Harris, 354 F. Supp. at 891.

224. Id. at 892 . 
In United States v. Frankfort Distilleries, ${ }^{225}$ the Supreme Court ruled that the powers of states under the twenty-first amendment did not preclude prosecution under the Sherman Act for agreements in restraint of the hquor trade. ${ }^{226}$ The Court held that the amendment granted states full authority to establish the conditions for hquor imports and to manage the regulatory mechamism for liquor that had arrived in the state, but "it does not follow from that fact that the Umited States is wholly without power to regulate the conduct of those who engage in interstate trade outside the jurisdiction of the State of Colorado."227

Modern cases reveal that courts have shown hittle tolerance for anticompetitive pricing agreements that are promulgated outside of core power purposes. In Rice v. Alcoholic Beverage Control Appeals Board, ${ }^{228}$ the Califorma Supreme Court invalidated a retail pricing system that prohibited liquor manufacturers from selling at below the price prescribed in a minimum price schedule. In rejecting an argument that the twenty-first amendment sheltered the hquor pricing mechanism from Sherman Act limitations, the court stated: "It is axiomatic that consideration of any state regulation of intoxicating beverages must begin with the Twenty-first Amendment. Yet it is equally clear the mquiry does not terminate at that point."229 The court then proceeded to apply the accommodation test established by Hostetter v. Idlewild Bon Voyage Liquor Corp. ${ }^{230}$ Balancing the state interests in "temperance and orderly marketimg conditions" 231 agamst the federal interest in "free and unfettered" competition, ${ }^{232}$ the court came down on the side of the federal interests. The court doubted whether the price mamtenance laws promoted temperance, and stated that there were alternatives other than mandatory price fixing to achieve the same goals. ${ }^{233}$

The Umited States Supreme Court struck the same balance two years later im finding unconstitutional California's minimum wine pricing mechamism, which operated in the same way as the distilled liquor system in Rice. In California Retail Liquor Dealers Association v. Midcal Aluminum, Inc., ${ }^{234}$ the Court admitted that the state's regulatory power within the areas of importation of liquor and structuring of the distribu-

225. 324 U.S. 293 (1945).

226. Id. at 299.

227. Id.

228. Rice v. Alcoholic Bev. Control Appeals Bd., 21 Cal. 3d 431, 435, 459, 579 P.2d 476, 479, 494-95, 146 Cal. Rptr. 585, 588, 603-04 (1978).

229. Id. at $447-48,579$ P.2d at $487,176 \mathrm{Cal}$. Rptr. at 596.

230. 377 U.S. 324 (1964).

231. Rice, $21 \mathrm{Cal}$. 3d at 451,579 P.2d at 490,146 Cal. Rptr. at 599.

232. Id. at 453, 579 P.2d at 441, 146 Cal. Rptr. at 600 (quoting Northern Pac. Ry. v. United States, 356 U.S. 1, 4-5 (1958)).

233. Id. at 459, 579 P.2d at 494, 146 Cal. Rptr. at 603.

234. 445 U.S. 97 (1980). 
tion system was virtually unlimited, but stated that when states attempt to exercise their "substantial discretion" over other areas of hiquor control, "those controls may be subject to the federal commerce power in appropriate situations." ${ }^{235}$ Invoking the balancing test for the various federal and state interests, the Court agreed with the Rice court that the federal interest prevailed and struck down the minimum wine pricing statute. ${ }^{236}$

As the Court has pared back its deference to statutes not mvolving core power, however, it has blurred its analysis. Instead of applying a deferential standard to statutes within the core power, the Court seems to have merely extended its balancing inquiry to all liquor statutes, core power or not.

For instance, in its most recent and definitive price-affirmance case, the Supreme Court lias best illustrated the distinction between the standard it announces and the standard it apphes. In 324 Liquor Corp. v. Duffy, ${ }^{237}$ New York liquor laws prohibited retailers from selling liquor at less than a twelve-percent markup over what they paid per bottle to the wholesaler. Since wholesalers could discount the price of cases to retailers witlout affecting the posted bottle price, retailers would often be forced to sell liquor at a minimum markup much higher than the statutory twelve percent. ${ }^{238}$

After concluding that the state statute conflicted with federal law, the Court stated that it would next seek to determine "whetlier the interests implicated by a state regulation are so closely related to the powers reserved by the twenty-first amendment that the regulation may prevail, notwithstanding that its requirements directly conflict with express federal policies."239 While it is clear that the state's "unsubstantiated interest in protecting small retailers" 240 could not come within its core power, the Court brushed off the state's argument that the laws promoted temperance. The Court stated: "One would hardly suggest that the New York Legislature set out to promote temperance by increasing the number of retail outlets for liquor."241 Even if the laws were intended to promote temperance, the Court ruled that they failed to do so, citing a lower court opimion. ${ }^{242}$ While the Court did not seriously consider the temperance argument in 324 Liquor Corp., it reserved judgment on

235. Id. at 110 .

236. Id. at 113-14; see also Rice, $21 \mathrm{Cal}$. 3d at 459, 579 P.2d at 494-95, $146 \mathrm{Cal}$. Rptr. at 603-04.

237. 479 U.S. 335 (1987).

238. Id. at 340 .

239. Id. at 347 (quoting Capital Cities Cable v. Crisp, 467 U.S. 691, 714 (1984)).

240. Id. at 350 .

241. Id. at 351 .

242. Id. (citing J.A.J. Liquor Store v. New York State Liquor Auth., 64 N.Y.2d 504, 521 n.2, 479 N.E.2d 779, 788 n.2, 490 N.Y.S.2d 143, 152 n.2 (1985)). 
whether a hquor pricing systein legitimately aimed at temperance could be upheld under the twenty-first amendment. ${ }^{243}$

By brushing aside the state's temperance argument, however, the Court clearly violated its own standard. While New York's hquor control mechanism may have lacked a reasonable relationship to temperance and was arguably a pretext, the Court did not discuss the case im those terms. Under its purpose-based mquiry, the Court should have determined first whether the statute was truly enacted under its core power. If so, the Court should have evaluated the law's rational relationship to its stated purpose. Rather, the Court proceeded directly to a balancing analysis that, in effect, afforded the state no more regulatory power over liquor than it had over cabbages.

Justice O'Colmor, dissenting, would have upheld the state statutes promulgated under the core twenty-first aniendment power. O'Connor's analysis, however, goes too far. She asserts that not only should the Court not be concerned with whether the legislature's laws were a wise choice, but also the Court should not care "whether the State of New York's motivation in doing so was linked to a 'central purpos[e]' of the Twenty-First Amendment."244 Although it protects the state's twentyfirst amendment power, Justice O'Connor's analysis fails because it lacks adequate protections against state overreaching. Without a purposebased element in the review, O'Connor's analysis opens the door for permicious statutes passed by states under the guise of liquor regulation. ${ }^{245}$

The line of cases culminating in 324 Liquor Corp. reveals a Supreme Court continuing to weaken the twenty-first amendment despite professing allegiance to deferential review of core power statutes. While the battle to maintain state control over hquor is not completely lost, the Court has indicated that increasingly it will replace the deference afforded state core-power liquor statutes with a standard that authorizes congressional preemption in the liquor area. This shift of power from the

243. Id. at $351-52$.

244. Id. at 360 (O'Connor, J., dissenting).

245. For examples of such statutes passed with this subterfuge in mind, see Wisconsin v. Constantineau, 400 U.S. 433 (1971) (police chief authorized to post notices in liquor establishment that persons he believed had drinking problems could not be served even though the affected person had no opportunity to be heard); Craig v. Boren, 429 U.S. 190 (1976) (statute allowed women to purchase $3.2 \%$ beer at age of 18 , while men liad to wait until they reached 21); Daugherty v. Daley, 370 F. Supp. 338 (N.D. Ill. 1974) (statute barred females from soliciting the purchase of drinks in a bar and prohibited serving female employees with beverages purchased by male bar patrons); Women's Liberation Union of R.I. v. Israel, 379 F. Supp. 44 (D.R.I. 1974) (statute prollibited serving women in bars that sold alcohol but did not sell food), aff'd, 512 F.2d 106 (1st Cir. 1975); United States v. Cantrell, 307 F. Supp. 259 (E.D. La. 1969) (racially motivated ordinance prohibited servicemembers in uniform from being admitted to bars); Sail'er Inn v. Kirby, 5 Cal, 3d 1, 485 P.2d 529, 95 Cal. Rptr. 329 (1971) (statute prohibited women from tending bar unless they owned the bar license or were married to the licensee). 
states to Congress became explicit in North Dakota v. United States. ${ }^{246}$

\section{B. Nortlı Dakota v. United States}

In its inost recent decision delineating states' riglits under the twenty-first amendment, North Dakota $v$. United States, ${ }^{247}$ the Court continued its abandonment of a purpose-based analysis. As in 324 Liquor Corp., the Court paid lip service to deferential review of liquor statutes passed under a state's core power, but then applied a searching preeniption inquiry.

The U.S. Government operates two federal enclaves, the Grand Forks Air Force Base and the Minot Air Force Base, in North Dakota. These enclaves are under the concurrent jurisdiction of the state and federal governments. ${ }^{248}$ Both bases operate clubs and packaged-goods stores that sell liquor to military personnel and their families. ${ }^{249}$

Federal regulations require the Department of Defense (DOD) to purchase alcoholic beverages other than beer and wine froin "the inost competitive source, price and other factors considered."250 Statutory history reveals that Congress specifically intended that profits froin these base clubs be used for the physical, emotional, and educational development of military personnel and their dependents ${ }^{251}$ and that liquor be procured at the inost advantageous price to maximize funds for these programs. $^{252}$

As part of its comprehensive schenie regulating mtoxicatmg beverages, ${ }^{253}$ North Dakota required all out-of-state liquor suppliers to affix to

246. 110 S. Ct. 1986 (1990).

247. Id.

248. Id. at 1991.

249. United States v. North Dakota, 856 F.2d 1107, 1108 (8th Cir. 1988).

250. 10 U.S.C. $\$ 2488(a)(1)$ (Supp. V 1987). Department of Defense regulations also provide that

the purchase of all alcoholic beverages for resale at any camp, post, station, base, or other DOD installation within the United States shall be in a manner and under such conditions as shall obtain for the government the nuost advantageous contract, price and other considered factors. These other factors shall not be construed as neaning any subnission to state control, nor shall cooperation be construed or represented as an admission of any legal obligation to submit to state control, pay state or local taxes, or purchase alcoholic beverages within geographical boundaries or at prices or froin suppliers prescribed by any state.

32 C.F.R. § 261.4 (1990).

251. 32 C.F.R. $\S 261.3$ (1990) ("It is the policy of the Department of Defense that Armed Services military clubs and package stores be established as an essential part of the DOD Morale, Welfare and Recreation (MWR) progran..").

252. Comnent, Pre-empting State Action Taken Pursuant to the Twenty-First Amendment, 53 TEMP. L.Q. 590, 596-600 (1980) (authored by Jerry M. Gewirtz).

253. North Dakota's liquor distribution system enıbraces three tiers: (1) suppliers/distillers; (2) resident wholesalers; and (3) resident retailers. Affidavit of North Dakota State Treasurer Robert $H$. Hanson, Joint Appendix at 33, North Dakota v. United States, 110 S. Ct. 1986 (1990) (No. 88-926) [hereinafter Hanson Affidavit]. 
each bottle of hquor sold to those federal installations a label stating that the hquor had to be consumed on those premises. ${ }^{254} \mathrm{~A}$ coinpanion regulation required all supphers to file a inonthly report showing the quantity of hquor shipped into the state during the preceding month. ${ }^{25 s}$ North Dakota enacted the labeling requirement to identify "intoxicants that are unlawfully diverted froin the federal enclaves into the state's doinestic commerce."256 Supphers could purchase these labels froin the state at three to five cents each, or distillers could print the labels themselves in a fornat approved by the state. ${ }^{257}$ North Dakota received no revenue froin the labels.

As a result of these labeling and reporting requireinents, several outof-state suppliers inforined the state that they would no longer supply hquor directly to the two federal bases, but would prefer to service the bases through in-state distributors. Another out-of-state distiller said that his prices would imcrease by amounts ranging froin 85 cents to 20 dollars and 50 cents per case, to cover the increased costs of ineeting the new regulation. ${ }^{258}$ The Umited States sought declaratory and injunctive rehef to invalidate the state regulations, alleging that the regulations interfered with the military's procurement of liquor and, therefore, should fall under the supreinacy clause. ${ }^{259}$ The state countered that the regulations did not conflict with federal law and, even if they did, that the twenty-first amendinent authorized the regulations to prevent the unlawful diversion of alcohol froin military enclaves into the internal commerce of North Dakota. 260

The state asserted that the regulations were an "iinportant aspect" of the estabhslied hquor distribution system, and, therefore, "should prevail as a proper exercise of its twenty-first amendment powers regardless of whether they conflict with federal pohcy."261 The United States

254. N.D. ADMIN. CODE $\S 84-02-01-05(7)$ (1986).

255. Id. § 84-02-01-05(1).

256. Hanson Affidavit, supra note 253, at 34 .

257. Id.

258. United States v. North Dakota, 675 F. Supp. 555, 556-57 (D.N.D. 1987).

259. "This Constitution, and the Laws of the United States which shall be made iu Pursuance thereof . . . shall be the supreme Law of the Land . . . ." U.S. CONST. art. VI.

The government contended that the increases required by the state regulations would force the government to obtain hquor for the bases at less competitive in-state sources, resulting in an added cost of more than $\$ 200,000$. Since this requirement directly contraveued Congress' directive to aequire liquor at the most coinpetitive cost, the government argued the regulations inust fall under the supreinacy clause. "The Court has long held that, under the Supremacy Clause, federal law preempts state regulation where the latter 'stands as an obstacle to the accomplishment and execution of the full purposes and objectives of Congress.' " Bricf for United States at 24-25, North Dakota v. United States, 110 S. Ct. 1986 (1990) (No. 88-926) (quoting Hines v. Davidowitz, 312 U.S. $52,67(1941))$.

260. United States v. North Dakota, 675 F. Supp. 555, 557 (D.N.D. 1987).

261. Brief for North Dakota at 13-14, North Dakota v. United States, 110 S. Ct. 1986 (1990) (No. 88-926). 
argued that "the limited scope of the twenty first amendment with respect to competimg constitutional commands"262 mandates that federal immunity "remains wholly unaffected by the amendment."263

The district court granted the state's motion for summary judgment. ${ }^{264}$ It analyzed first the threshold question of whether the state regulations conflicted with federal law and found no such conflict. "The state's regulations may have indirectly caused the price of out-of-state supplies of alcohohic beverages to mcrease, ${ }^{265}$ but they do not prevent the federal government from obtaining those beverages at the 'lowest cost.' The 'lowest cost' has merely increased."266

A divided panel of the Eighth Circuit Court of Appeals reversed. 267 In overturning the district court, the majority used a preemption analysis and exphicitly rejected the use of a twenty-first amendment mquiry.

The State correctly points out that federal interests generally may give way to weightier state interests when the state exercises its core power under the twenty-first amendment. That inay be so when a private party, for example, asserts a constitutional or federally-created right or interest against the state's use of its twenty-first amendinent power, but the Tax Commission II decision teaches that the state's 'virtually unlimited' authority reaches its limits when the state attempts to exercise that power over an imstrumentality of the federal government itself. ${ }^{268}$

The Eighth Circuit panel concluded, therefore, that the twenty-first amendment gave states no authority to regulate liquor procurement pohcies that Congress established. ${ }^{269}$ Even assuming that the state could

262. Brief for United States at 35-42, North Dakota v. United States, 110 S. Ct. 1986 (1990) (No. 88-926). The United States cited as support Craig v. Boren, 429 U.S. 190, 206 (1976) (equal protection clause not trumped by twenty-first amendment); Department of Revenue v. James B. Beam Distilling Co., 377 U.S. 341 (1964) (export-import clause); Wisconsin v. Constantineau, 400 U.S. 433 (1971) (due process clause); Collins v. Yosemite Park \& Curry Co., 304 U.S. 518 (1938) (taxation of exclusive federal enclave); United States v. Mississippi Tax Comm'n, 412 U.S. 363 (1973) (Mississippi Tax Comm'n I) (taxation of federal enclaves); United States v. Mississippi Tax Comm'n, 421 U.S. 599 (1975) (Mississippi Tax Comm'n II) (same).

In its reply brief, North Dakota distinguished the above cases on the grounds that the Court explicitly found that regulations at issue in many of the cases lay outside core twenty-first amendment power. Reply Brief for North Dakota at 2, North Dakota v. United States, $110 \mathrm{~S}$. Ct. 1986 (1990) (No. 88-926).

263. Brief for United States at 38, North Dakota y. United States, 110 S. Ct. 1986 (1990) (No. 88-926).

264. United States v. North Dakota, 675 F. Supp. 555, 559 (D.N.D. 1987).

265. The federal government asserted-and the state did not dispute-that its costs would increase $\$ 200,000$ to $\$ 250,000$ per year if it were required to purchase all distilled spirits from local wholesalers, but the record did not indicate how much liquor the government would be forced to purchase from local wholesalers on account of the regulations. United States v. North Dakota, 856 F.2d 1107, 1113 n.9 (8th Cir. 1988).

266. North Dakota, 675 F. Supp. at 557.

267. North Dakota, 856 F.2d at 1114.

268. Id. at 1111 (citations omitted).

269. Id. at 1112 . 
invoke its authority under the twenty-first amendment, the Court found that the federal government's interest clearly prevailed. ${ }^{270}$

Chief Judge Lay argued in dissent that the state's regulations were neither a tax on the federal government nor an atteinpt to regulate liquor consumption on a federal enclave, ${ }^{271}$ both of which would be clearly impermissible. ${ }^{272}$ Instead, wrote Lay, the regulations were intended to prohibit the diversion of liquor into the state's doinestic cominerce and the Supreme Court has "clearly observed that the twenty-first amendment provides states with the authority to prohibit diversion of liquor that is imported to federal enclaves located withm its boundaries."273 The chief judge warned that to refuse to recoguize a twenty-first amendment protection for the statute "is to eradicate any real meaning to the core provisions of the twenty-first anendment." 274 Since the state regulates importation of raw materials, general operation of distilleries, einployinent relations, bottling, and shipping - all of which can increase the cost of hquor for the federal governinent-it is "ridiculous" to assume that the "inilitary shall be exempt froin the effects of all types of state regulation in its procurement of liquor."275

The Supreme Court reversed. ${ }^{276}$ In a plurality opinion, Justice Stevens found that the regulations were within the state's core twentyfirst ainendment power and, therefore, were subject to deferential scrutiny. ${ }^{277}$ Nevertheless, the Court ignored its own call for deference, and einbarked on a standard preemption balancing analysis. The Court's abandoument of twenty-first amendment powers was clear. While it found the regulations withm the state's core power and concluded that the state regnlation did not conflict with federal law, ${ }^{278}$ the Court nonetheless proceeded to consider the state and federal interests in a preemption analysis.

The Court rejected the United States' contention that the North

270. Id. at 1112-13.

271. Id. at 1115 (Lay, C.J., dissenting).

272. See, e.g., Mississippi Tax Comm'n I, 412 U.S. 363, 375 (1973) ("[T]he Twenty-first Amendment confers no power on a State to regulate-whether by licensing, taxation, or otherwisethe importation of distilled spirits into territory over which the United States exercises exclusive jurisdiction."); Mississippi Tax Comm'n II, 421 U.S. 599, 613 (1975) ("We reach the same conclusion as to concurrent jurisdiction bases ....").

273. North Dakota, 856 F.2d at 1115 (Lay, C.J., dissenting) (citing Mississippi Tax Comm'n I, 412 U.S. $363,377-78$ (1973)).

274. Id.

275. .Id. at 1116.

276. North Dakota v. United States, 110 S. Ct. 1986 (1990) (Justice Stevens' plurality opinion was joined by Chief Justice Rehnquist and Justices White and O'Connor).

277. Id. at 1994 ("Given the special protection afforded to state liquor control policies by the Twenty-first Amendment, they are supported by a strong presumption of validity and should not be set aside lightly ....").

278. Id. at 1998. 
Dakota laws regulated federal activity and should, therefore, fall under the supremacy clause. The Court stated: "Over 50 years ago . . . the Court decisively rejected the argument that any state regulation which indirectly regulates the Federal Government's activity is unconstitutional, and that view has now been 'thoroughly repudiated." "279 According to this view, a regulation is invalid only where it directly regulates the federal government or discriminates against it. ${ }^{280}$ Since North Dakota's regulatory framework was more favorable to federal government suppliers than to in-state suppliers, it could not be considered discriminatory. ${ }^{281}$ Turning to its preemption analysis, the plurality found that, because Congress had not spoken directly to the regulation at issue, the Court was in no position to balance the state and federal interests. The plurality stated: "It is Congress, not this Court, which is best situated to evaluate whether the federal interest in procuring the inost inexpensive hquor outweighs the State's legitimate interest in preventing diversion."282 In so ruling, the Court stated that Congress could override state hquor regulations by specifically exeinpting the military from these regulations. ${ }^{283}$ This analysis betrays the purpose of the twenty-first amendinent.

If the twenty-first amendinent ineans anything, it ineans that a state may regulate the importation and distribution of intoxicating liquors. As Justice Jackson noted in 1941, "It certainly applies to nothing else."284 Therefore, the plurality erred in using a standard preeinption analysis. By treating the federal government's power to regulate liquor no differently than the government's power to regulate "cabbages and candlesticks"285 or "peanuts and potatoes,"286 the Court nullified the only positive grant of power to states in the Constitution, at least as relates to dealings with the federal government. ${ }^{287}$

In a concurring opimion joined by no other Justice, Justice Scalia

279. Id. at 1994 (citing South Carolina v. Baker, 485 U.S. 505, 520 (1988)).

280. Id. at 1995.

281. Id. at 1996-97.

282. Id. at 1999.

283. Id. at 1997 ("Congress has the power to confer immunity from state regulation on government supphers beyond that conferred by the Constitution alone, eveu when the state regulation is enacted pursuant to the State's powers under the Twenty-first Amendment . . . .') (citations omitted).

284. Duckworth v. Arkansas, 314 U.S. 390, 399 (1941) (Jackson, J., concurring).

285. Carter v. Commonwealth of Va., 321 U.S. 131, 139 (1944) (Frankfurter, J., concurring).

286. United States v. Frankfort Distilleries, 324 U.S. 293, 300 (1945) (Frankfurter, J., concurring).

287. In dissent, Jnstice Brennan, joined by Justices Marshall, Blackmun, and Kennedy, would have further eviscerated the twenty-first amendment. Jnstice Brennan wrote that the Court has never held that a state regulation aimed at preventing the unlawful diversion of liquor "is insulated from review under the federal immunity doctrine or any other constitutional ground, including the dormant Commerce Clanse." North Dakota, 110 S. Ct. at 2003 (Brennan, J., dissenting). 
attempted to vindicate the twenty-first amendment. "The Twenty-first Amendment . . . is binding on the Federal Government like everyone else, and empowers North Dakota to require that all liquor sold for use in the State be purchased from a hicensed in-state wholesaler. Nothing in our Twenty-first Amendment case law forecloses that conclusion."288 Scalia argued that, accordimg to the Court's precedents, states may not tax government hquor establishments but may regulate them: "Federal immunity from state taxation . . . is at least arguably consistent with the text of the Twenty-First Amendment's prohibition on transportation or importation im violation of state law. Federal immunity from state hquor import regulations is not." 289

The case law, however, is more readily harmomized on a purposebased distmction. If North Dakota's hquor labeling law were an attempt to tax the government, the regulation would fail. But since all three courts concluded that the regulation was a bona fide attempt to prevent unlawful diversion, ${ }^{290}$ the Court's analysis should have been restricted to whether the regulation bore a rational relationship to its intended purpose.

District Judge Conmy and Chief Judge Lay of the Eighth Circuit paved a partial course for the proper apphication of the purpose-based accominodation analysis estabhished by the Supreme Court. First, a court must ascertain whether an actual conflict has arisen. Judge Coniny ruled there was no such conflict. ${ }^{291}$ Under a proper application of the analysis, the inquiry would have ended there. Since no conflict with federal law has arisen, the statutes should be considered valid exercises of the state's twenty-first amendment power. Judge Conmy, however, proceeded with the analysis as if the court had found a conflict. ${ }^{292}$ Coniny determined next whether the state had passed the statute for a core purpose. Conmy found that the statute was passed to prevent the diversion of hiquor from the state's two military bases and was not a pretext. ${ }^{293}$ Therefore, finding a core purpose, the district court should next have

288. Id. at 2001 (Scalia, J., concurring).

289. Id.

290. United States v. North Dakota, 675 F. Supp. 555, 559 (D.N.D. 1987); United States v. North Dakota, 856 F.2d 1107, 1113 (8th Cir. 1988); North Dakota v. United States, 110 S. Ct. 1986 (1990). Despite the decisions by the two lower courts, the United States continued to charge that the regulations were designed to force the military to buy more liquor from in-state sources. Brief for United States at 33-34, North Dakota v. United States, 110 S. Ct. 1986 (1990) (No. 88-926). The state vigorously disagreed, pointing out that in-state wholesalers "are subject to a far more intricate and burdensome regulatory scheme" that includes licensure, reporting, and bonding requirements, as well as a business privilege tax. Reply Brief for North Dakota at 11, North Dakota v. United States, 110 S. Ct. 1986 (1990) (No.88-926). Moreover, the state treasurer was empowered to examine the books and facilities of a wholesaler at any time to determine compliance. Id.

291. North Dakota, 675 F. Snpp. at 557.

292. Id. at 558 .

293. Id. at 558-59. 
determined whether the state's statutes were rationally related to the prevention of diversion. This is where Conmy's analysis strayed.

Conmy, like the Supreme Court, balanced state and federal interests. This balancing analysis flies in the face of a purpose-based analysis. If a court must weigh the state and federal imterests regardless of whether the statute was passed under the state's core power, the twenty-first amendment is toothless. If the state passes a law to restrict consumption of hiquor, the court's balancing inquiry would treat it no differently than if the state passed a law to restrict consumption of milk.

Chief Judge Lay, in a dissent to the Eighth Circuit opinion, properly framed the analysis. After concluding that no conflict existed between the federal and state law, Lay argued that a preemption analysis was iniproper. ${ }^{294}$ By virtue of the twenty-first amendinent, the state faces no commerce clause limitations when it properly restricts the distribution of intoxicants. The Supreine Court's preeinption analysis of a core-power statute strips the twenty-first amendinent of any real meaning. ${ }^{295}$ Therefore, Chief Judge Lay's analysis is the only approach that will properly treat liquor differently from other articles of commerce.

As this country learned through the temperance embroilments of the 1880 s and Prohibition, liquor is like nothing else. For no other itein is state and local control so necessary, and for no other itein does the United States Constitution expressly provide for state control.

The Supreme Court's analysis of state statutes regulating hquor has changed substantially since adoption of the twenty-first amendment. Much of this change was necessary to rem in states that abused their regulatory control over liquor and trampled on constitutionally protected individual rights or skirted the prohibition on taxing the federal government. But in checking state abuses, the Court has eviscerated the central premise of the twenty-first amendment-that liquor control ought to be local.

North Dakota $v$. United States might stand for no more than the proposition that Congress can preempt state hquor regulations only when the regulation directly affects the federal government. In its broadest readimg, however, the case could stand for the proposition that Congress has the power to preempt state liquor regulations, even if those laws were enacted for a proper core-power purpose.

The variety of problems-whether real or imagined-created by a free trade in liquor continues the compellimg justification for local control. On the other hand, state power must be reasonably adapted toward actually controlling the flow of liquor. The purpose-based, three-step

294. North Dakota, 856 F.2d at 1115 (Lay, C.J., dissenting).

295. See id. 
analysis presented in this Comment proposes to secure a balance of these two central concerns.

\section{CONCLUSION}

While the Supreme Court has been whittling away at the power granted to states under the twenty-first amendment, it has continued to recognize that special deference should be accorded state statutes promulgated under the amendment's core power. This recognition not only coinports with the history and langnage of the amendment, but it is also the only remnant of life remaining in the amendment that states fought so hard to implement. In the actual application of its accommodation analysis, however, the Court has failed to vimdicate the power of states to control intoxicating hiquor. Moreover, the Court's attack on the twenty-first amendment has gone largely uunoticed.

This lack of notice results primarily from the Court's continued verbal deference to states' rights. But only when the Court goes beyond inere verbal deference and properly apphes the accommodation balance to protect these rights will the twenty-first amendment be resuscitated and states' rights be vindicated.

The Supreine Court properly has recognized that the twenty-first amendment should not empower states to run roughshod over federal and imdividual rights. The rights of both federal and state governments must be accommodated. A workable analysis would guarantee states the power to regulate the consumption, distribution, and importation of intoxicating hquor, while at the same time it would protect federal powers and individual rights.

The three-step analysis proposed in this Comment first determines whether the state statute conflicts with federal law. If the laws conflict, the analysis inust then determine if the state statute was promulgated under the state's core twenty-first amendment power. A statute is within the core power unless it is passed for a reason other than to regulate hiquor, or unless it is not rationally related to a permissible purpose. If the regulation falls outside the core powers given to states by the twentyfirst amendinent, the Court inust balance federal and state interests to determine if the statute must fail under the supremacy clause. Permissible state regulations will often infringe on federal and individual rights. Only by gnarding the central purpose of the twenty-first amendment, however, will the Court protect the states' hard-won power to control intoxicating hquor within their borders. 